\title{
\#IranVotes: Political Discourse on Iranian Twitter during the 2016 Parliamentary Elections
}

\section{Citation}

Marchant, James, Amin Sabeti, Kyle Bowen, John Kelly, and Rebekah Heacock Jones. 2016. \#IranVotes: Political Discourse on Iranian Twitter during the 2016 Parliamentary Elections. Internet Monitor Special Report Series, June 2016.

\section{Permanent link}

http://nrs.harvard.edu/urn-3:HUL.InstRepos:27377992

\section{Terms of Use}

This article was downloaded from Harvard University's DASH repository, and is made available under the terms and conditions applicable to Other Posted Material, as set forth at http:// nrs.harvard.edu/urn-3:HUL.InstRepos:dash.current.terms-of-use\#LAA

\section{Share Your Story}

The Harvard community has made this article openly available.

Please share how this access benefits you. Submit a story. 


\section{\#IranVotes}

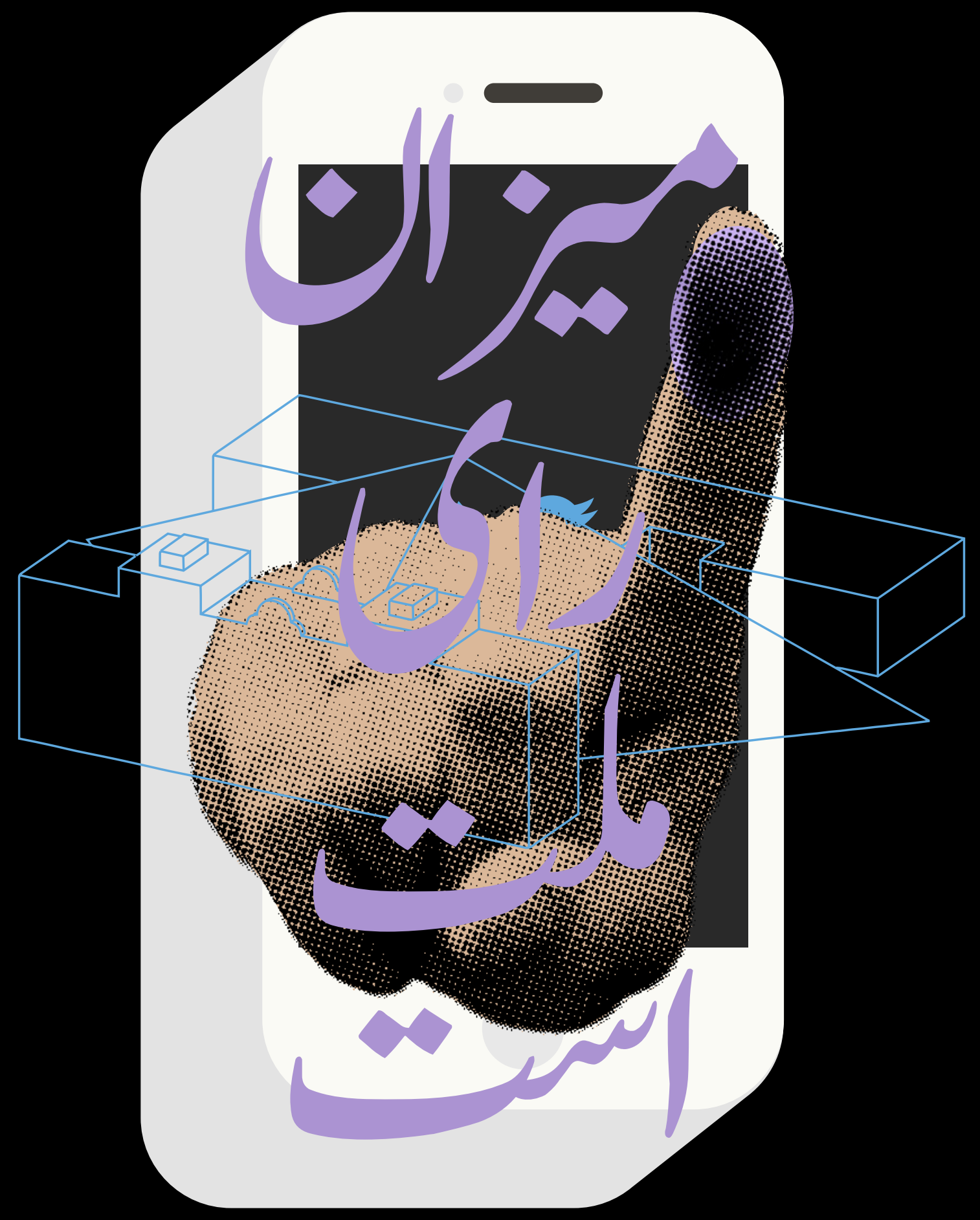

Political Discourse on

Iranian Twitter During the 2016

Parliamentary Elections 


\section{\#IranVotes}

Political Discourse on

Iranian Twitter During the 2016

Parliamentary Elections

James Marchant, Amin Sabeti, Kyle Bowen, John Kelly, Rebekah Heacock Jones

JUNE 2016

(c) (1) (3) (2) 


\section{About Small Media}

Small Media is a London-based action lab that provides digital research, training and advocacy solutions to support the work of civil society actors globally Small Media has previously published a globally. Small Media has previously publishec variety of research on Iran's online publics, including: Unmasking the Arzeshi: Iran's Conservative Cyber Activists, National Fabric: Iran's Ethnic Minorities, and Revolution Decoded: Iran's Digital Media Landscape.

\section{About Internet Monitor}

Internet Monitor is a research project based at Harvard University's Berkman Center for Internet

\& Society. Internet Monitor's aim is to evaluate, describe, and summarize the means, mechate, describe, and sums, and extent of Internet content controls and Intern activity around the world. The project helps researchers, advocates, policymakers, and user communities understand trends in Internet health and activity through research, analysis, and data visualization.

More information at thenetmonitor.org

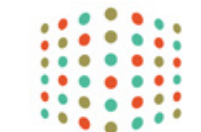

INTERNET MONITOR
Acknowledgements

The authors gratefully acknowledge the support an help of the many people who contributed to this research. Rob Faris, Jonathan Zittrain, and Urs Gasse offered invaluable guidance, support, and advice.

The data and maps used in this paper are courtesy of Graphika, Inc.

More information at www.graphika.com

\section{graptitia}




\section{Abstract}

In this study, we map and analyze the content and tructural features of the Iranian Twittersphere as exhibited over the course of the 2016 legislative elections in order to identify the communities that developed around various political, social, and cultural issues and to assess the influence of online political campaigning that emerged on the platform over the course of the election campaign. Given Iran's ongoin fforts to control and restrict freedom of expression around numerous political, social, and cultural issues in public spaces, we are interested to assess how users make use of the uncensored space provided by Twitter to speak out about various contentious issues. We achieve this by engaging in network analysis and content analysis of tweets and media content posted over the course of the election period.

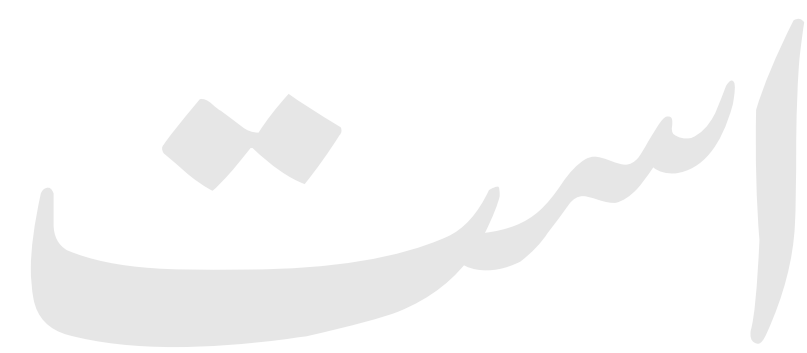

Although Twitter remains blocked by the Iranian authorities, the widespread use of circumvention tools by Iranian citizens has allowed them to make use of it as a free and open space for public engagement around contentious and divisive political and social issues. Using a mixed-methods approach combining social network analysis with qualitative content analysis of election-related content of the Iranian Twittersphere during the elections, we identify and analyze 46 clusters of users ranging from human rights activists through to reformist and conservative political commentators, technology advocates, and literature enthusiasts. In addition to these inte observe that the network is home to extensive networks of everyday users, who share jokes, idle chatter, and flirtatious messages. Although the Twittersphere hosts a significant volume of political content, it is by no means a purely politica space.

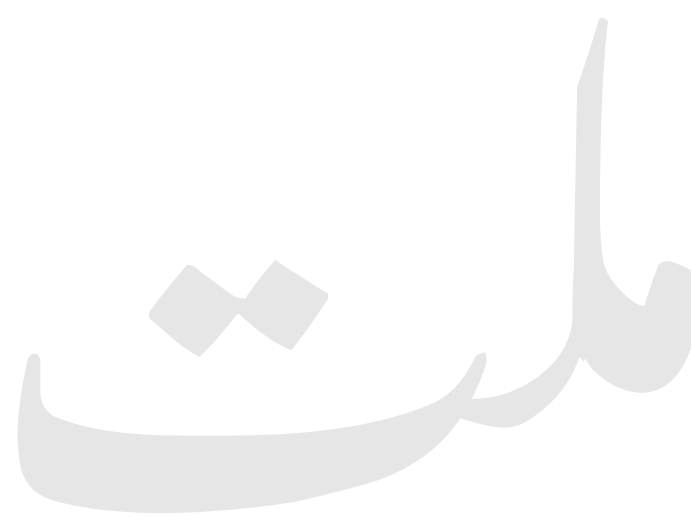

The intense online activity of the Iranian diaspora and the extent of its engagement with digital networks of activists and journalists inside the Islamic Republic is another major feature of the Iranian Twittersphere that we explore in this study-we observe that the level of interconnectedness between diasporic and domestic networks is remarkably high indicating that the Iranian Twittersphere offers more than just an uncensored space for activists inside Iran, but provides Iranians in exile with the opportunity to engage with the development of political and social discourses

inside the country.

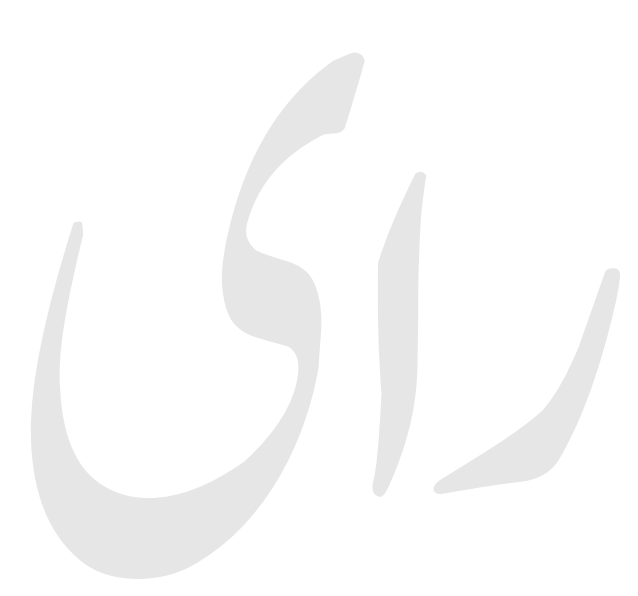

We find that the scale of Twitter activity amongst diaspora Iranians and more liberal segments of Iranian society has had two major impacts upon the political makeup of the Twittersphere: firstly, a general politicization of the Twittersphere; and secondly, the squeezing out of politically divergen voices - especially from conservative factions, who appear to have found their home on alternative (unblocked) social networking sites. Although it does not necessarily hold a hugely politically diverse or representative chunk of Iranian netizens, the Iranian Twittersphere does function as an important bridge to connect the country's vast diaspora networks to politically engaged, reformist-leaning citizens living inside Iran.

Originally spoken by the Islamic Republic's founder Ayatollah Khomeini, the official slogan of the 2016 elections translates roughly as: 'Only the nation's vote matters.' 


\section{Contents}

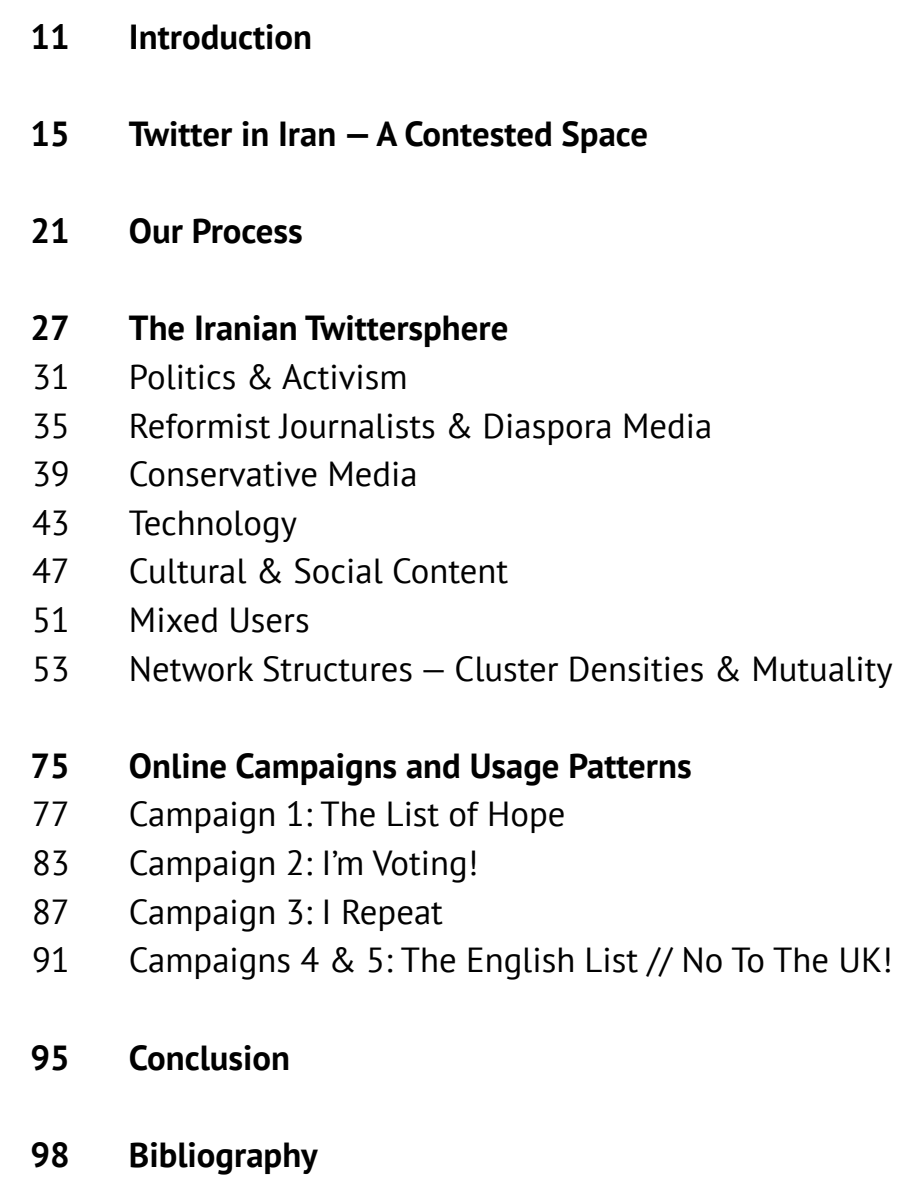




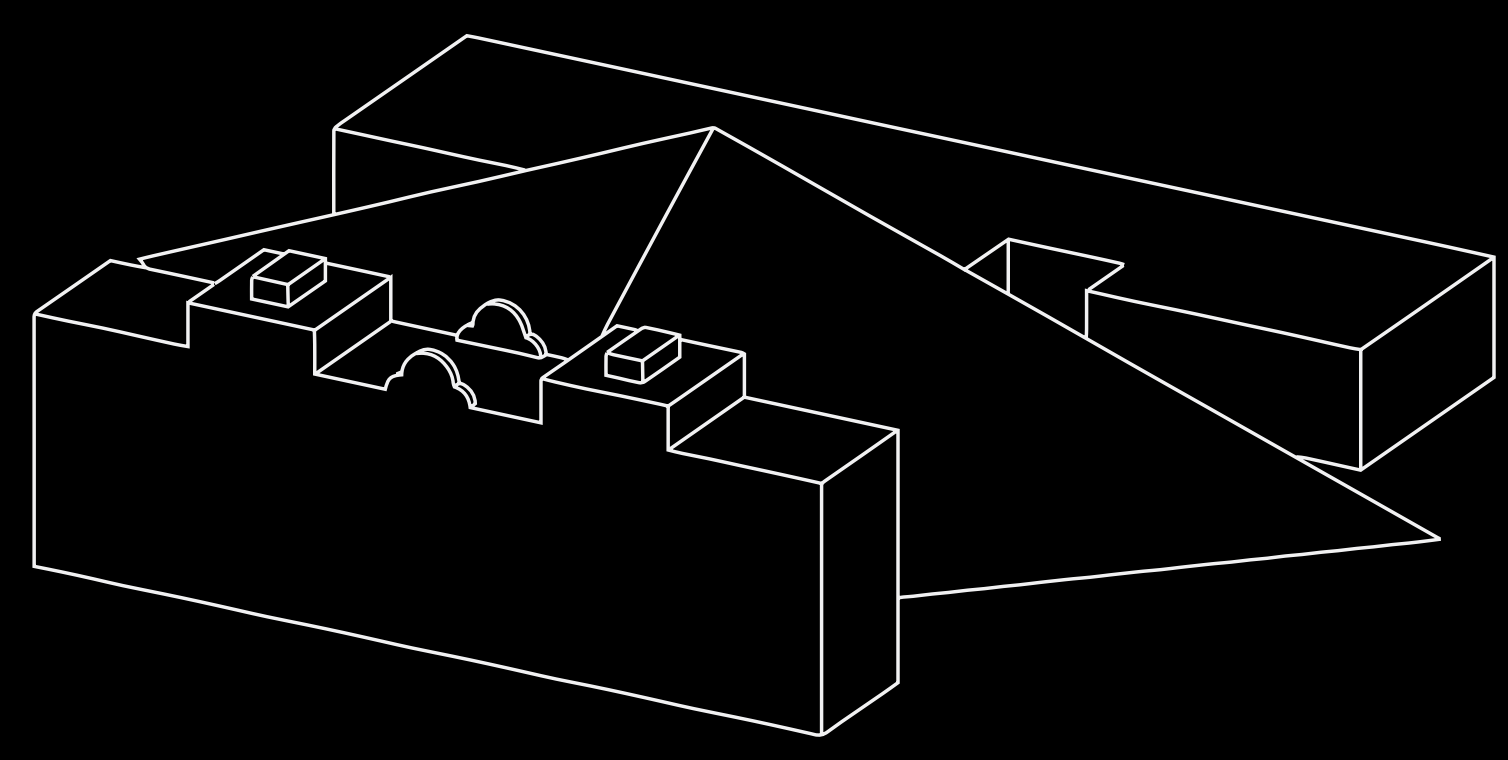

\section{Introduction}

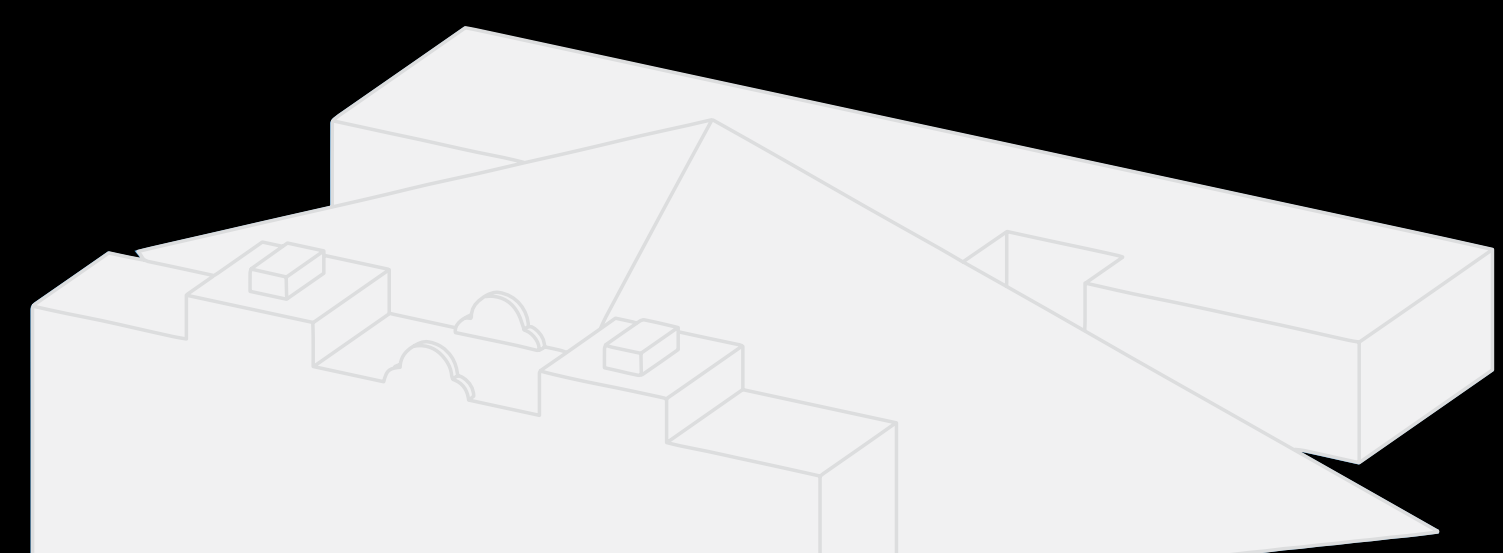
information control in the world today. Iran's extensive program of online censorship has seen it labeled as an 'enemy of the Internet' by Reporters Without Borders ${ }^{1}$ and described as the 'least free' country in terms of internet freedom by Freedom House between 2011-142 (surpassed only by China in its 2015 report $^{3}$ ). In response, Iranian tech activists in Iran and the diaspora have collaborated to develop tools and strategies for evading censorship, and as a consequence VPN usage in the country is sky-high-the Iranian Students' News Agency reported in usage in the country is sky-high-the Iranian Students' News Agency reported in
2014 that just under $70 \%$ of young Iranian internet users employ circumvention tools to access restricted content.

Despite the challenges of censorship, Iranians have long taken to online spaces to express their opinions on contentious political, cultural, and social issues. For many years, Iran's blogosphere-or 'Blogestan'-was one of the largest and most vibrant online public spaces in the world. In 2008, the Berkman Center for Internet \& Society undertook a comprehensive analysis of the Iranian blogosphere, finding a politically and culturally diverse ecology comprised of reformists, consenvatives, literature enthusiasts, and religious youth. ${ }^{5}$ However, since 2008 Iran's online ecology has undergone a series of dramatic changes, triggered in part by the development of new platforms, and in other ways by the intensification of online censorship in the wake of the 2009 post-election unrest.

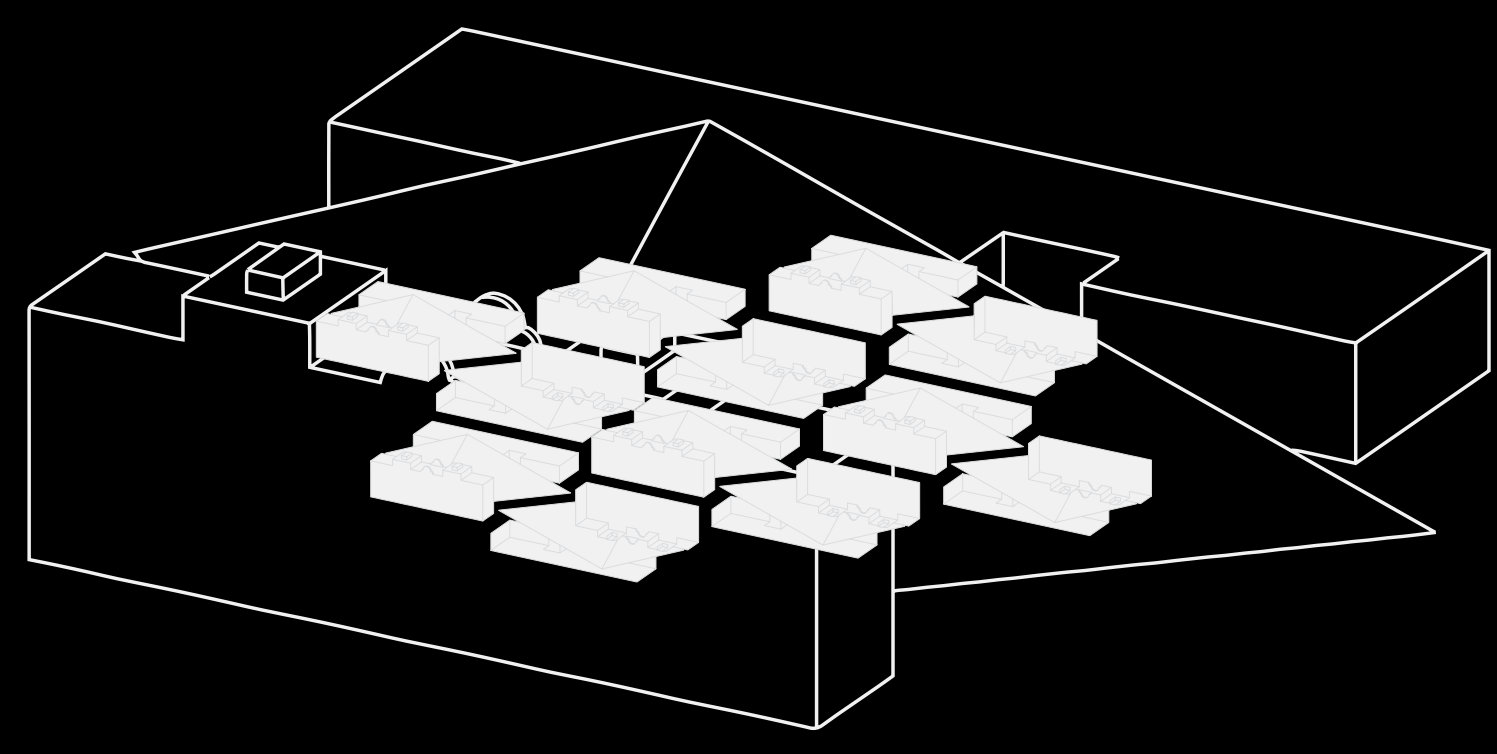

1 Reporters Without Borders, "Internet Enemies Report 2012", (2012), last accessed: 5/11/2016, http://bit.ly/RwoB12

2 Freedom House, "Freedom on the Net 2014", (2014), last accessed: 5/11/4/2016, httpp://bit.ly/ FrdHse14

3 Freedom House, "Freedom on the Net 2015", (2015), last accessed: 5/11/2016, http://bit.lly/ FrdHse15

4 ISNA, "The results of the latest youth survey have been published", (2014), last accessed: 5/11/2016, http://bit.ly/IrVPNyth

5 John Kelly, Bruce Etling, "Mapping Iran's Online Public: Politics and Culture in the Persian Blogosphere", (2008), last accessed: 5/11/2016, http://bit.ly/Brklro8 
Since 2008 the Persian-language blogosphere has been in terminal decline. The Iran Media Project's 2014 report 'Whither Blogestan?' described how the meteoric rise of social networking sites (SNSs) such as Facebook and Twitter had delivered a mortal blow to Iran's blogosphere, ${ }^{6}$ owing to these sites' interactivity, accessibility, and ability to embed and share media content seamlessly. This trend has continued despite the Iranian government's aggressive campaign to block access to many globally popular SNSs inside the country, including Twitter-the microblogging service that was credited by numerous observers for playing a significant role in the post-election unrest of 2009. ${ }^{7}$

This study assesses the composition and character of the Iranian Twittersphere over the course of the hotly contested 2016 parliamentary and Assembly of Experts elections. It does so by mapping the communities that have developed around different political, cultural, and social issues and exploring the activity patterns of the platform's users. In this way, we demonstrate how the Iranian Twittersphere is an ideologically diverse network of individuals and communities who are using the platform to advance particular social and political causes (while sharing plenty of cat pictures along the way). The 2016 elections offered an excellent opportunity to monitor the volume and significance of political activity on Twitter during a period of heightened political engagement. What we found over the course of this study is a highly politically engaged, and heavily reformist-leaning network of Iranian citizens and diaspora-based users.

6 Laurent Giacobino, Arash Abadpour, Collin Anderson, Fred Petrossian, Caroline Nellemann, "Whither Blogestan: Evaluating Shifts in Persian Cyberspace", (2014), last accessed: 5/11/2016, http:///bit.ly/shftsprsncbirspce

Mike Musgrove, "Twitter is a Player in Iran's Drama", Washington Post 06/16/2009, last accessed: 5/11/2016, http://bitly Wapoglt 


\section{2}

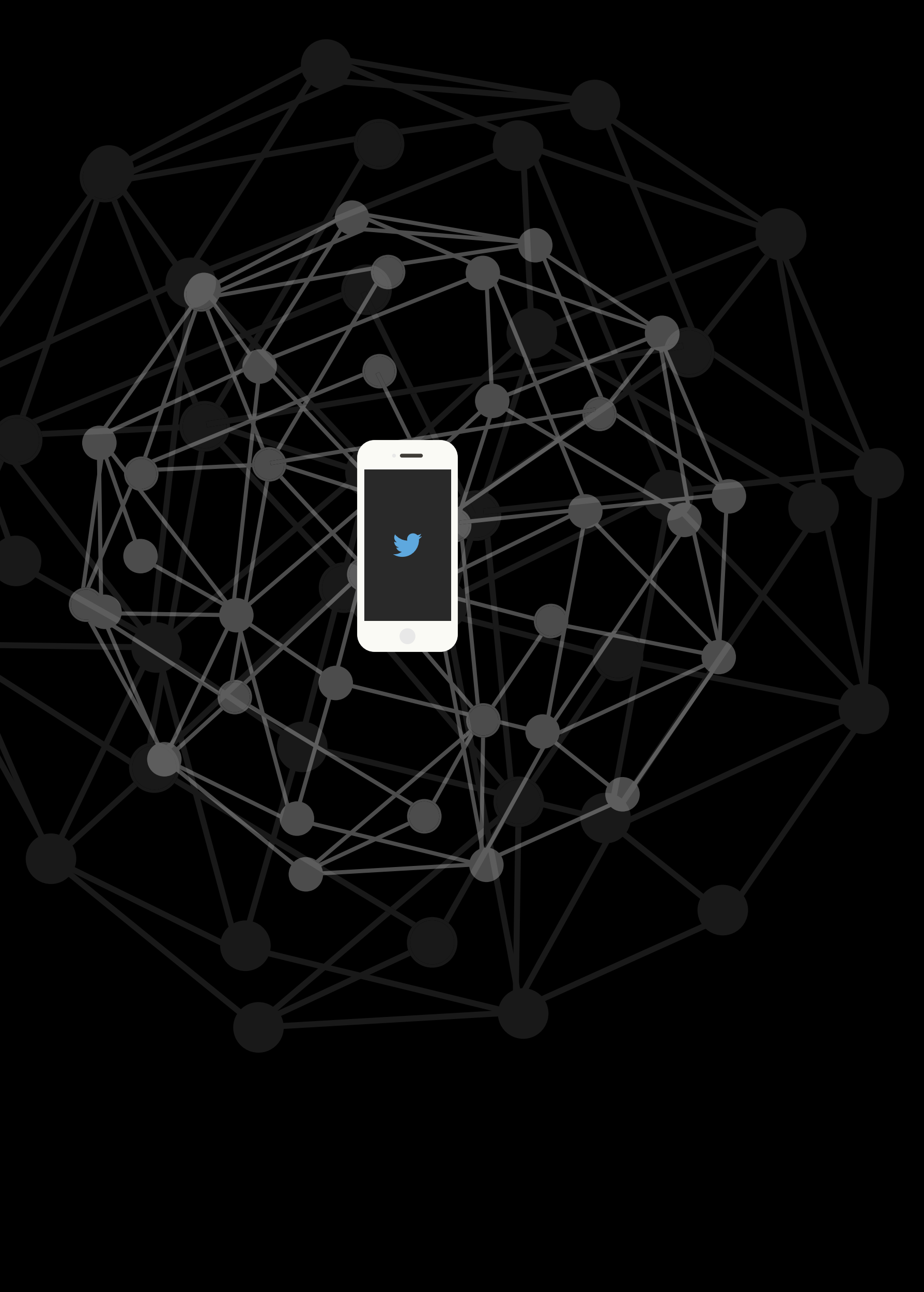

\section{Twitter in Iran - A Contested Space}

When protests erupted in the streets of Tehran following the disputed presidential elections of 2009, many Western commentators were quick to celebrate Twitter's role in the uprising. Former US national security adviser Mark Pfeifle went so far as to suggest that the popular micro-blogging site should get the Nobel Peace Prize because "without Twitter the people of Iran would not have felt empowered and confident to stand up for freedom and democracy."

The widespread perception that Twitter was integral to the protests prompted an official at the US state department to ask Twitter to postpone scheduled maintenance in order to keep the platform online for Iranian users. ${ }^{9}$ Everyone seemed to agree that Twitter was a crucial enabler of the movement.

The celebratory discourse about Twitter revolutions almost certainly overstated Twitter's role in the uprising ${ }^{10}$. Former Persian editor of Global Voices Hamid Tehrani argued that "the West was focused not on the Iranian people but on the role of Western technology. Twitter was important in publicising what was happening, but its role was overemphasized." ${ }^{\text {11 }}$ But there's no doubt that the events of 2009 prompted Iranian authorities to take a much greater interest in Twitter. Some of that interest took the shape of censorship; Twitter was first blocked in Iran in 2009. Yet there were also indications that authorities recognized the propaganda value offered by the micro-blogging site.

One example cited by Iranian-American journalist Golnaz Esfandiari is the story of Saeedeh Pouraghayi, an Iranian activist allegedly arrested, raped, and murdered for shouting "Allah Akbar" on her rooftop, that spread rapidly on Twitter and other

8 Mark Pfeifle, "A Nobel Peace Prize for Twitter?" The Christian Science Monitor 07/06/2009, last accessed: 5/11/2016, http:///bit.ly/ChrScMlr

a Ewan MacAskill, "Us confrrms î asked Twiter to stay open to help Iran protesters", The Guardia 6/17/2009, last accessed: 5/11/2016, http://bit.ly/GulrTo9

10 Evgeny Morozov, The Net Delusion: How Not to Liberate the World (New York: Penguin Books, 2012), 1 - 32.

11 Matthew Weaver, "Iran's 'Twitter Revolution'was exaggerated, says editor", The Guardian 06/09/2010, last accessed: 5/11/2016, http:///bit.ly/lrTwRGua 
SNSs. ${ }^{12}$ As it turned out, the story was a hoax. Pouraghayi later appeared on state TV saying that on the night she was said to have been arrested, she escaped by jumping off her balcony. According to Esfandiari, a reformist website later claimed that the Iranian government had planted the story to create doubt about activists' allegations of post-detention rape and pave the way for further arrests of opposition leaders. ${ }^{13}$ It seems that Twitter, concludes Esfandiari, "can serve the purposes of Iran's regime as easily as it can aid the country's activists." ${ }^{14}$

As the above example indicates, the Iranian government responded to the (perceived) popularity of Twitter following the 2009 protests with a mix of repression and propaganda. Both responses continue to this day: Twitter is still inaccessible without circumvention tools, and a number of Iranian officials maintain active profiles. What these reactions have in common is a perception that Twitter is an important medium for Iranians that could pose a threat to the government.

\section{Twitter in Iran Today}

While the world's attention has moved on from its intense focus on the use of Twitter in the 2009 protests, the Iranian Twittersphere remains a vibrant and contested space today. One notable development in recent years is the frequent use of Twitter-in English-by Iranian officials. Supreme Leader Ali Khamenei, President Hassan Rouhani, and Foreign Minister Javad Zarif all maintain active Englishlanguage Twitter accounts in addition to their Persian-language profiles (though only Zarif's account is certified). Both Rouhani and Zarif have engaged with other prominent users on the platform, such as Twitter CEO Jack Dorsey and US Senator Tom Cotton (see Figures 1.1 \& 1.2).

[Figure 1.1]

ranian President Hassan

Rouhani tweeting at

Twitter CEO Jack Dorsey

Jack ejack 1 Oct 2013

@HassanRouhani Good evening, President. Are citizens of Iran able to read your tweets?

$$
\text { \& } \quad \text { Ł.7 } 1.5 \mathrm{~K} \quad 0957 \quad \ldots
$$

\section{Hassan Rouhani}

(3) HassanRouhan

$2+$ Follow

Evening, @Jack. As I told @camanpour, my efforts geared 2 ensure my ppl'll comfortably b able 2 access all info globally as is their \#right.

\section{$\begin{array}{ll}\text { RETWEETS } & \text { UKES } \\ 2,122 & 1,419\end{array}$

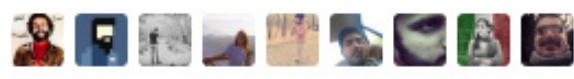

9:24 PM - 1 Oct 2013

12 Golnaz Esfandiari (2010), "The Twitter Devolution”, Foreign Policy 06/08/2010, last accessed: 5/11/2016, http://bit.ly/TwDevlr

"What's behind the bogus testimony of Saeedeh Pouraghayi?" (Archived), Norooz News 09/27/2009, last accessed: 5/11/2016, http:///archive.is/NyOas

14 Esfandiari, “The Twitter Devolution”.
Serious diplomacy, not macho personal smear, is what we need. Congrats on Ur new born. May U and Ur family enjoy him in peace .@SenTomCotton

\section{RETWEETS LKES \\ 11:39 AM - 30 Apr 2015

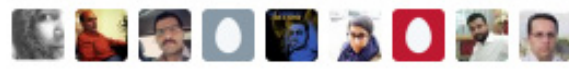

The use of English indicates that these profiles are not primarily aimed at a domestic audience. Yet it appears that the Iranian government has recognized the value of using Twitter to get its message out. This does not mean that Twitter will be officially unblocked anytime soon; although there were reports that Twitter briefly became accessible without circumvention tools following the implementation of the 2015 nuclear agreement, it appears this was more likely the result of a technical glitch than a deliberate policy decision. ${ }^{15}$

Twitter remains reasonably popular among ordinary Iranians. According to the Minister of Culture and Islamic Guidance, Twitter has over 4 million Iranian users. ${ }^{16}$ The platform has hosted discussions on a wide range of topics, from travel tips ${ }^{17}$ to internet censorship, ${ }^{18}$ the refugee crisis, ${ }^{19}$ and the nuclear deal. ${ }^{20}$

Iranians have also been adept at using Twitter for campaigning. Last year, Iranian netizens successfully used the platform to lobby Twitter executives to add Iran to Twitter's mobile list, where users can add their mobile numbers in order to enable 2-step verification. ${ }^{21}$

While the resulting shift to Twitter's registration policy had little political significance (though it did improve security for Iranian users), it does suggest that Twitter does give Iranians a venue in which to organize and push for policy

15 Small Media, "Iranian Internet Infrastructure and Policy Report, December 2015", (January 2016), p. 8 last accessed: 5/11/2016, http:///bit.ly/IIIPD15

acebook and Twitter, ILNA 02/06/2015, last 16 "More than 14 million Iranians are on Viber,
accessed: $5 / 11 / 2016$, http://brk.mn/ilna2015

17 “Must See Iran on Twitter”, Financial Tribune 10/16/2014, last accessed: 5/11/2016, http://bit. ly/MSeelr14

18 Small Media, "Iranians' Best Five Reactions to Iran's Crappy Internet," (2015), last accessed: 5/11/2016, http://bit.ly/cppynetnov

19 Small Media, "Iranians Tweet On: The Refugee Crisis,"(2015), last accessed: 5/11/2016, http:// bit.ly/itorfg

20 Small Media, "Iranians Tweet On: The Deal", (2015), last accessed: 5/11/2016, http://bit.ly/ itoirndl

21 Lorenzo Franceschi-Bicchierai, "Twitter adds Iran, Cuba and 20 other countries to location options", Mashable 01/27/2015, (2015), last accessed:5/11/2016, httn'/(bitly/rCubMsh 
subject for conservatives. The zealous hype about the 2009 'Twitter Revolution' notwithstanding, Twitter still serves as potent reminder of protests they refer to as the sedition:22 In 2010, Supreme Leader Ayatollah Khamenei accused Twitter of trying to help protesters. ${ }^{23}$ But this hasn't stopped him from using Twitter for his own ends. As mentioned above, Supreme Leader Ayatollah Khamenei maintains active (and often combative) accounts in several languages.

The growth of Twitter and other SNSs such as Facebook has transformed Iran's online ecology. Iran's sprawling 'Blogestan' (mapped out in a 2008 report by the Berkman Center for Internet \& Society) appeared to go into retreat in the face of the meteoric rise of SNSs inside Iran. The 2014 report 'Whither Blogestan' concluded that the growth of SNSs has played a significant role in the decline of Iran's blogosphere, with users migrating to platforms such as Twitter and Facebook to share their everyday thoughts, muse about poetry and literature, and engage in political debate and discussion. ${ }^{24}$

Twitter occupies a special place in the Iranian internet ecosystem. It is viewed as a symbol of the 2009 protests by both the authorities and Green Movement supporters alike, while the latter also see Twitter as a tool of American interference. It is widely used by activists, young people, and the tech community in Iran and the diaspora, but also by Iranian leaders such as the President, the Foreign Minister, and the Supreme Leader. Finally, Twitter has played a significant role in discussions surrounding Iran's recent elections for both parliament and the Assembly of

Experts, as we explain in this study.

22 Shahir Shahidsaless, "Behind the recent turmoil in Iran's parliament", Al Monitor 01/18/2015, last accessed: 5/11/2016, http://bit.ly/AlMlirPar

23 Amin Sabeti, "Ayatollah Khamenei's website uses social networks", Iran Media Program 12/18/2010, last accessed: 5/11/2016, http://bit.ly/KhamSoMd

24 Giacobino, Abadpour, Anderson, Petrossian, Nellemann, “Whither Blogestan: Evaluating Shifts in Persian Cyberspace." 


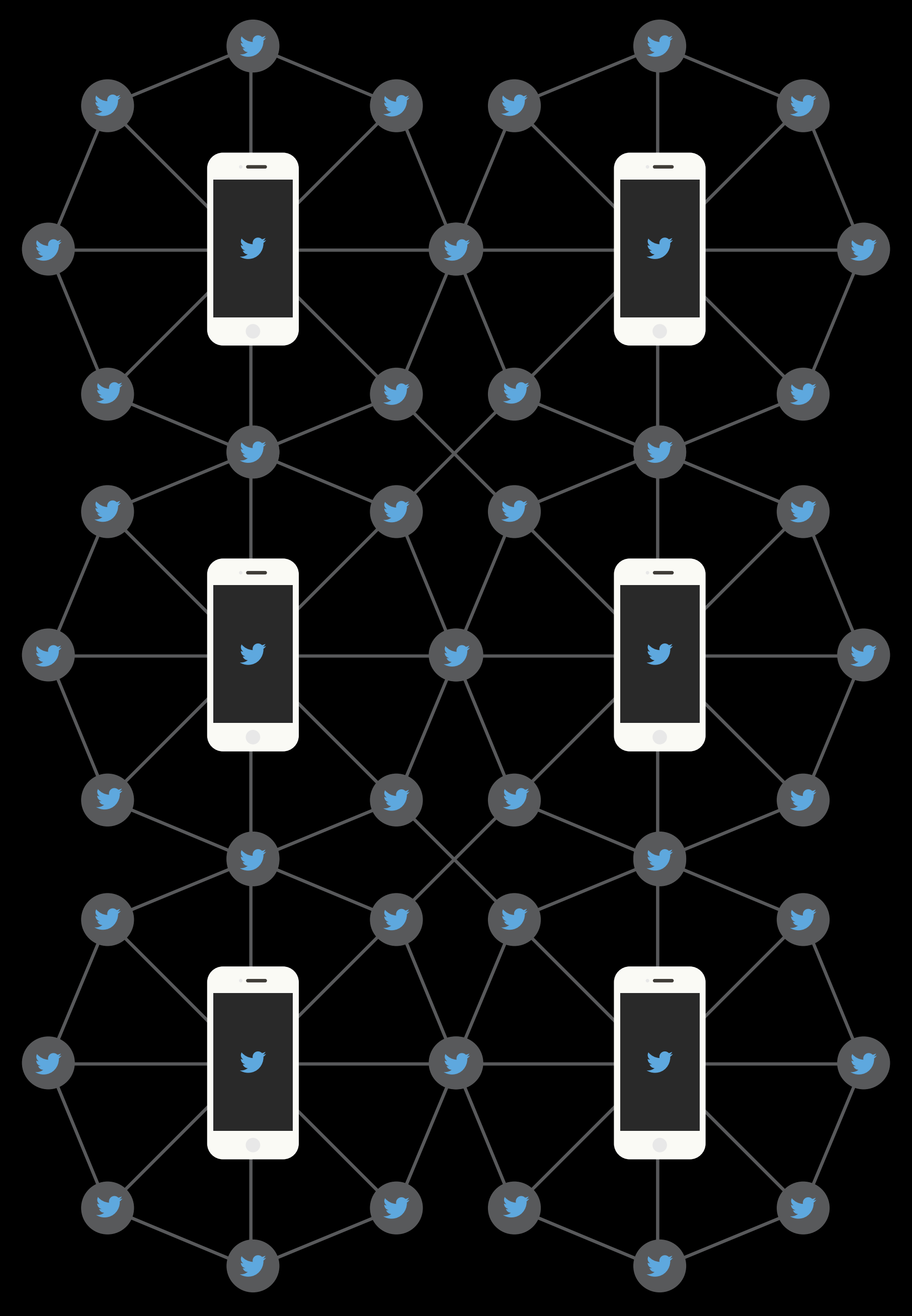

\section{Our Process}

The analysis in this study is based on a mixed methods research protocol that includes qualitative content analysis of Persian-language Twitter supported and guided by algorithmically drawn network maps and a diverse set of quantitative metrics calculated for each of the clusters in the network. This methodological approach builds upon similar efforts in the past to map online discussion spaces that correspond that correspond to particular geographic

We began by generating a social network map of Persian-language Twitter accounts based on the follow relationships between users (see Figure 4.1). The network structure is visualized using a physics model layout algorithm (FruchtermanRheingold), overlaid with colors representing each account's assignment to a group based on a clustering of network relationships. The resulting network map and structures that emerge reflect the individual decisions of Twitter users to follow other users, and the work of the algorithm that transforms these follow relationships into clusters.

In the visualizations, each node represents a single user account, and the size of each node reflects the number of followers from the network to that account. The location of each node relative to the others is based on the collective follow decisions of all of the nodes in the netwr decisions of all of the nodes in the network. Accoun relationships are pulled together as though by a spring or forced of gravity. Densely interconnected network neighborhoods "bunch up" in the map. In this way, one can think of the map as a picture of the pattern of influence and information flow in the network.

The location of nodes on the map is based on follow relationships and reflects longer term stable relationships. Drawing a map based on mentions and retweets would put more emphasis on shorter term interests, influenced more by the content of tweets within the period in which data are collected.

25 Bruce Etling, John Kelly, Robert Faris, and John Palfrey, "Mapping the Arabic Blogosphere: Politics and Dissent Online, "New Media \& Society 12 (2010), pp. 1225-1243. John Kelly, Vladimir Barash, Karina Alexanyan, Bruce Etling, Robert Faris, Urs Gasser, and John Palfrey, Mapping Russian Twitter," Berkman Center Research Publication, 03/20/2012, last accessed: 5/11/2016, http:/ bit.ly/BrkRusTw 
together to develop a 'seed list' of several hundred Persian-language Twitter

accounts, based on Small Media's knowledge of the Iranian Twittersphere and

previous analysis undertaken by Graphika. This set was expanded by adding all

of the followers of the seeds, and then reduced by removing all accounts with no activity over the prior 90 days. A clustering algorithm assigns each node in the map to a particular cluster, which are represented by different colors. These clusters

are based on commonality in outward facing attention. Accounts that use similar

language (including hashtags), interact with the same accounts, and share the same URLs are drawn together.

A variety of metrics are calculated to help researchers understand and describe the contours and structures of the map. These metrics provide a quantitative measure of which activities occur proportionately more often in each cluster compared to

the others, including:

- Twitter accounts followed

- Twitter accounts mentioned, retweeted, and replied to within a timeframe

- URLs cited in tweets

- Words used, including bigrams and trigrams (pairs and triples)

- Countries, cities, and other locations mentioned in user profiles

Researchers apply labels to each of the clusters based on a review of this data. These labels are not meant to categorize each account within a given cluster but rather offer concise shorthand descriptions for the various clusters. The clusters vary by the interests and perspectives of the users in each cluster, though some clusters do overlap in the topics that they discuss. Each user offers a unique

perspective that does not necessarily map perfectly with the set of common themes found in each cluster. For many of the accounts within a cluster, the cluster label offers a good summary of the primary focus and general orientation of the account; for other accounts, the cluster label may not strongly capture the interests and views of the user.

The first iteration of this map included 40 clusters, which Small Media categorized into nine thematic groups:

\begin{tabular}{|c|c|}
\hline GROUP & CLUSTER \\
\hline \multirow{2}{*}{ Entertainment } & Satire (3) \\
\hline & Mixed Entertainment \& Daily Tweets \\
\hline \multirow{2}{*}{ Politicians } & Iranian Politicians \\
\hline & Reformists \& Opposition \\
\hline \multirow{2}{*}{ News \& Journalism } & Mixed Journalists (4) \\
\hline & Business Journalists \\
\hline \multirow{4}{*}{ Technology } & Tech Developers (2) \\
\hline & Bloggers \\
\hline & Tech Consumers \\
\hline & Entrepreneurs \\
\hline \multirow{2}{*}{ Culture } & Mixed Literature (5) \\
\hline & Mixed Cultural \\
\hline \multirow{4}{*}{ Western Sources } & Western Media \\
\hline & Western Politicians \\
\hline & Western Celebrities \\
\hline & Other Media \\
\hline \multirow{3}{*}{ Mixed Users } & Daily Tweets (4) \\
\hline & Satire \\
\hline & Mixed Miscellaneous (2) \\
\hline Kurdish Users & Kurdish Activists (2) \\
\hline \multirow{2}{*}{ Regional Users } & Pakistani Users (2) \\
\hline & Afghan Users (3) \\
\hline
\end{tabular}


For the second round of mapping, we removed the non-Persian speaking clusters (Pakistani, Kurdish, and Afghan users) in order to focus our analysis on Persian language content. We subsequently applied a filter to the map, by which only Twitter accounts with at least one Persian-language tweet will appear. After applying these filters, we redrew the map. This iteration provided us with more readily identifiable communities and more overtly political clusters compared with our first map, including groups of hardliners, reformists, and pro-Mujahedin-e Khala (MEK) users - a community that previous Small Media research has revealed to be very prolific on Twitter. ${ }^{26}$ The final map includes 12,040 nodes, a dataset that is rich in detail and resolution while being of a tractable size for quantitative and qualitative analysis. 


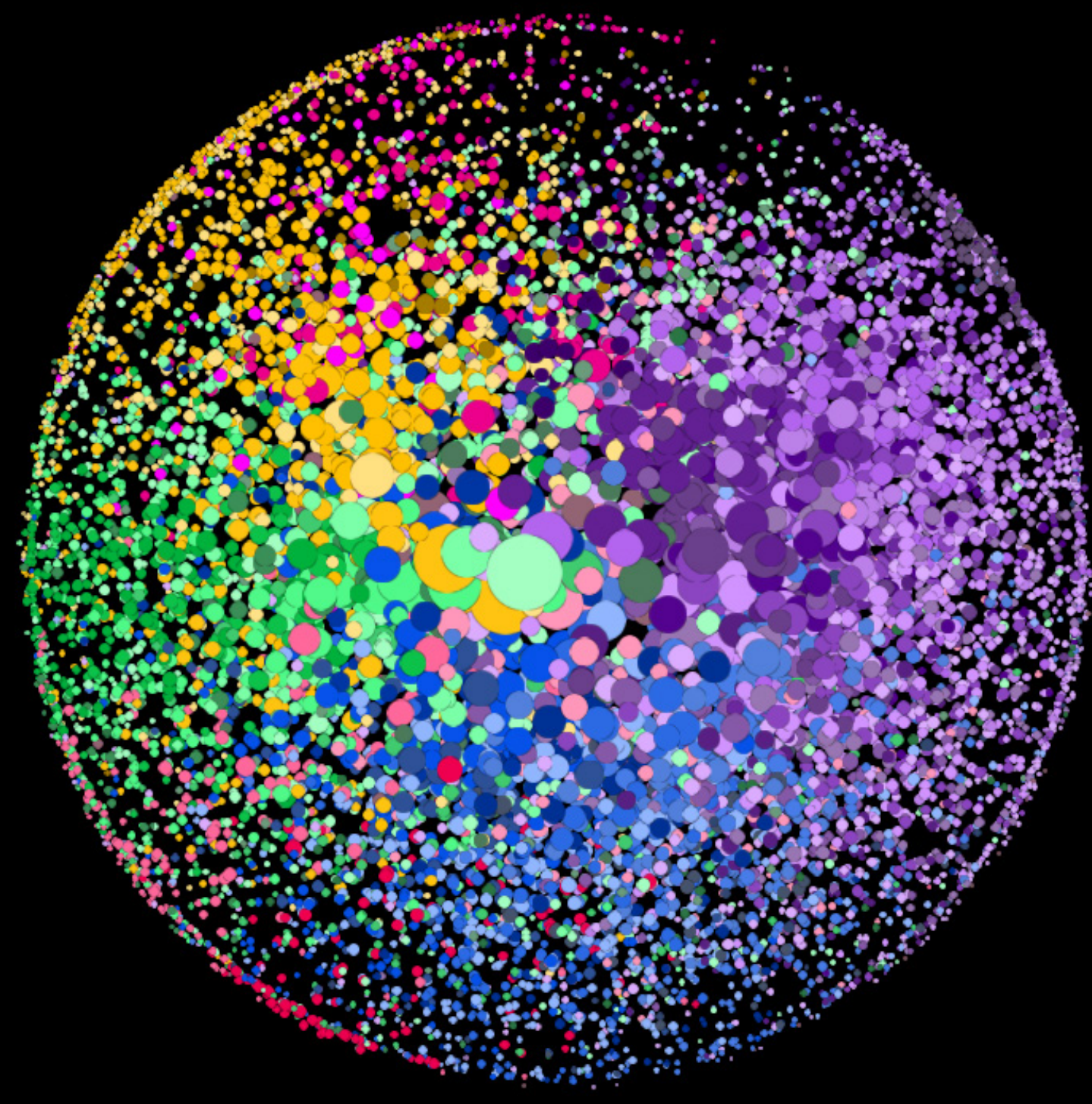
Conservative Media
Reformist \&
Technology
Politics \& Activism
Mixed Users

4

The Iranian

Twittersphere

Our research uncovered 46 clusters of users within our network, of which a large number overlapped in terms of frequently posted content and the types of discussions and user engagements that took place. As a consequence, a number of these clusters have been grouped together in our analysis to ensure clarity in the narrative overview below.

\begin{tabular}{l|l|l}
\hline \multirow{2}{*}{$\begin{array}{l}\text { Core Influencers } \\
\text { Politics \& }\end{array}$} & $\begin{array}{l}\text { Highly influential accounts that broadcast to large } \\
\text { audiences but do not engage with other users } \\
\text { directly. }\end{array}$ \\
\cline { 2 - 3 } $\begin{array}{l}\text { Anternational Human } \\
\text { Rights }\end{array}$ & $\begin{array}{l}\text { A collection of international and diaspora-based } \\
\text { lranian HROs, along with prominent human rights } \\
\text { activists in exile. }\end{array}$ \\
\cline { 2 - 3 } & Mujahedin-e Khalq & $\begin{array}{l}\text { An isolated cluster of MEK-aligned activists and } \\
\text { automated bot accounts. }\end{array}$ \\
\cline { 2 - 3 } & $\begin{array}{l}\text { Opposition \& Reformist } \\
\text { Activists }\end{array}$ & $\begin{array}{l}\text { Diaspora-based human rights activists and } \\
\text { organizations, generally advocating for political } \\
\text { change inside Iran. }\end{array}$ \\
\hline
\end{tabular}




\begin{tabular}{|c|c|c|}
\hline \multirow{8}{*}{$\begin{array}{l}\text { Reformist \& } \\
\text { Diaspora Media }\end{array}$} & Afghan Media & $\begin{array}{l}\text { A peripheral cluster of Afghan journalists and } \\
\text { media consumers. }\end{array}$ \\
\hline & Diaspora Media (2) & $\begin{array}{l}\text { Iranian diaspora news agencies and television } \\
\text { networks and their followers. }\end{array}$ \\
\hline & $\begin{array}{l}\text { Shargh Journalists \& } \\
\text { Reformists }\end{array}$ & $\begin{array}{l}\text { Dominated by journalists from the reformist } \\
\text { newspaper Shargh. }\end{array}$ \\
\hline & $\begin{array}{l}\text { Iranian Journalists \& } \\
\text { Diaspora Media }\end{array}$ & $\begin{array}{l}\text { A mixture of reformist-leaning journalists from } \\
\text { Iran and the diaspora. }\end{array}$ \\
\hline & Diaspora Commentariat & $\begin{array}{l}\text { A tight community of high-profile diaspora } \\
\text { journalists, activists, and political commentators. }\end{array}$ \\
\hline & $\begin{array}{l}\text { Opposition \& Reformist } \\
\text { Journalists }\end{array}$ & $\begin{array}{l}\text { A mixture of reformist journalists and media } \\
\text { commentators more harshly critical of the Islamic } \\
\text { Republican system. }\end{array}$ \\
\hline & Reformist Journalists (2) & $\begin{array}{l}\text { Clusters of reformist journalists and media } \\
\text { consumers, predominantly based inside Iran. }\end{array}$ \\
\hline & Mixed Media Consumers & A loose cluster of low-influence media consumers \\
\hline \multirow{2}{*}{$\begin{array}{l}\text { Conservative } \\
\text { Media }\end{array}$} & Conservative Media & $\begin{array}{l}\text { Dominated by conservative journalists and critics } \\
\text { of the Rouhani administration. }\end{array}$ \\
\hline & Clerics \& Hardline Media & $\begin{array}{l}\text { Mixed cluster of clerical critics of the Rouhani } \\
\text { administration and hardline conservative } \\
\text { journalists. }\end{array}$ \\
\hline
\end{tabular}

\begin{tabular}{|c|c|c|}
\hline \multirow{5}{*}{ Technology } & Iranian Bloggers & $\begin{array}{l}\text { Iranian tech bloggers, many of whom have } \\
\text { previously been active in Iran's blogosphere. }\end{array}$ \\
\hline & Iranian Entrepreneurs & $\begin{array}{l}\text { Iranian entrepreneurs and enthusiasts about the } \\
\text { potential of Iran's tech sector. }\end{array}$ \\
\hline & Iranian Startups & $\begin{array}{l}\text { Tech entrepreneurs posting frequently about } \\
\text { tech startups in Iran. Supportive of international } \\
\text { engagement. }\end{array}$ \\
\hline & Tech Developer (2) & $\begin{array}{l}\text { Tech developers working in Iran's technology } \\
\text { sector. }\end{array}$ \\
\hline & $\begin{array}{l}\text { Tech Developers \& } \\
\text { Bloggers }\end{array}$ & A mixed cluster of tech developers and bloggers. \\
\hline \multirow{7}{*}{$\begin{array}{l}\text { Cultural \& } \\
\text { Social Issues }\end{array}$} & Iranian Musicians & $\begin{array}{l}\text { A cluster dominated by a number of Iranian bands } \\
\text { and independent musicians. }\end{array}$ \\
\hline & Literature \& Poetry (5) & $\begin{array}{l}\text { Clusters in which users share literary quotes } \\
\text { and poetry. Most quotes are from Persian poets } \\
\text { (classical and modern), but some English- } \\
\text { language literary content is also shared. }\end{array}$ \\
\hline & $\begin{array}{l}\text { Mixed Literature \& } \\
\text { Politics }\end{array}$ & $\begin{array}{l}\text { Mixed cluster of literature- and poetry-sharing } \\
\text { users, and users engaging with (predominantly } \\
\text { reformist) politics. }\end{array}$ \\
\hline & Nostalgic Periphery & $\begin{array}{l}\text { Peripheral users sharing poetry, literature, and } \\
\text { historical images. Some users are supporters of } \\
\text { the deposed Pahlavi dynasty. }\end{array}$ \\
\hline & Porn Consumers & $\begin{array}{l}\text { Users in this segment share social content and } \\
\text { limited pop culture content. They also mention } \\
\text { and retweet pornographic content more than any } \\
\text { other cluster in the network. }\end{array}$ \\
\hline & $\begin{array}{l}\text { Social Issues \& Daily } \\
\text { Tweets (5) }\end{array}$ & $\begin{array}{l}\text { Users in these mixed groups tweet about pop } \\
\text { culture, literature, social issues, and some political } \\
\text { issues. }\end{array}$ \\
\hline & Vocal Critics & $\begin{array}{l}\text { A cluster dominated by harsh critics of the Islamic } \\
\text { Republic. Users in this cluster are tightly bound, } \\
\text { with high levels of density and reciprocity. }\end{array}$ \\
\hline Mixed Users & Daily Tweets (9) & $\begin{array}{l}\text { Users in these clusters typically share updates } \\
\text { about their lives, daily observations, and some } \\
\text { limited engagement with social and political } \\
\text { issues. }\end{array}$ \\
\hline
\end{tabular}




\section{Politics \& Activism}

Clusters in the Politics \& Activism group are fairly diverse, but include key politica figures in the Iranian establishment, high-profile opposition and reformist activists, and a handful of international human rights organizations.

Users in these clusters post frequently about ongoing political developments and human rights issues, including freedom of expression, press freedom, minority rights, and political prisoners. Many Iranians in these clusters are critical of the Islamic Republic's institutions and leaders, and advocate for political change. Many of these political commentators and activists are Iranians living in exile, including former Green Movement activists, nationalists, and royalists. This group also contains a cluster of dedicated Mujahedin-e Khalq (MEK) Supporters. The Politics \& Activism golitics \& Activism group contains the lowest number of users who publicly state they live inside Iran, at $30.7 \%$. This is compared to $42.3 \%$ of users who state that they live outside the country.

The central cluster of Core Influencers is made up of accounts with very high numbers of followers and very low numbers of followed accounts. These include the accounts of President Hassan Rouhani (English- and Persian-language), Supreme Leader Khamenei, news agencies such as Deutsche Welle Persian and Radio Farda, and the women's rights activist Masih Alinejad.

Although these accounts have little in common thematically, they are all 'broadcaster' accounts in that they produce information to large networks of followers without having any great interest in interacting with other users-they are information disseminators, not consumers.

The International Human Rights cluster contains a number of diaspora-based human rights organizations, including civil society organizations Tavaana and TavaanaTech, United4Iran, and the Iranian Human Rights Documentation Center (HRDC) It also contains a number of diaspora-based Green Movement-aligned accounts including 'Persin Bano' and 'Madyar' as well as the account of the accounts including 'Persian Banco and 'Madyar' as well as the account of the deposed Crown Prince Reza Pahlavi, who now positions himself as a human rights advocate. 
There is some crossover between the previous cluster and the Opposition \& Reformist Activists cluster, which also contains a number of online activists closely associated with the Green Movement. This cluster appears to be made up of a mixture of Iran-based and diaspora-based activists.

Although the clusters in this group all advocate for some variety of political change in Iran, they are poorly connected with each other, and there are few indicators of significant cooperation. As well as posting tweets critical of Iran's human rights record, a number of users in this cluster post GIFs, videos and cartoons mocking Iranian politicians.

News sources particularly influential amongst activists in these clusters include opposition-leaning sources, including the online-only reformist newspaper Kaleme $e^{27}$ and Iranwire, ${ }^{28}$ but also Iran-based sources including the Iranian Student's News Agency, ${ }^{29}$ international human rights organizations such as Amnesty Internationa and Iran Human Rights, ${ }^{30}$ as well as The Guardian. ${ }^{31}$

The Mujahedin-e Khalq-aligned accounts effectively constitute a different network entirely. The MEK are an exiled opposition movement with a very limited following in Iran. Their decision to fight alongside Saddam Hussein's forces in the Iran-Iraq War effectively destroyed their legitimacy inside the country, and their reputation has been bruised further by reports of human rights abuses against their own members ${ }^{32}$ and accusations of cult-like practices.

They engage with an entirely separate and isolated media ecology, including the National Council of Resistance of Iran, ${ }^{34}$ Mohajedin.org, ${ }^{35}$ Maryam-Rajavi.com, ${ }^{36}$ Hambastegi Meli, ${ }^{37}$ Iran News Update, ${ }^{38}$ and Iran Efshagari. ${ }^{39}$ All of these accounts are openly or semi-openly affiliated with the MEK, criticize Iran's human rights record aggressively, and advocate openly for regime change.

The vast majority of pro-MEK Twitter users are on the periphery of the wider network and interact only with other MEK users. High-influence MEK users interact with individuals in the International Human Rights segment on a semi-regula

27 Kaleme, last accessed: 5/11/2016, http://www.kaleme.com

28 Iranwire, last accessed: 5/11/2016, https://iranwire.com

29 ISNA, last accessed: 5/11/2016, http://isna.it

30 Iran Human Rights, last accessed: 5/11/2016, http://persian.iranhumanrights.org

31 The Guardian, last accessed: 5/11/2016, http://www.theguardian.com

32 Human Rights Watch, "No Exit: Human Rights Abuses Inside the MKO Camps", (2005), last accessed: 5/11/2016, http://bit.ly/HRW MEK

33 Owen Bennett Jones, "An Iranian mystery: Just who are the MEK?" BBC News 04/15/2012, last accessed: 5/11/2016, http:///bit.ly/BBCMEK

34 National Council of Resistance of Iran, last accessed: 5/11/2016, http://ncr-iran.org

35 People's Mojahedin of Iran, last accessed: 5/11/2016, http://mojahedin.org

36 Maryam Rajavi, last accessed: 5/11/2016, http://maryam-rajavi.com

37 Hambastegi Meli, last accessed: 5/11/2016, http://hambastegimeli.com

38 Iran News Update, last accessed: 5/11/2016, http://irannewsupdate.com

39 Iran Efshagari, last accessed: 5/11/2016, http://www.iran-efshagari.com/english
[Figure 4.3]

A post from the English language account of MEK leader Maryam Rajavi basis through targeted tweets or the use of human rights-related hashtags. (MEK leader Maryam Rajavi's English-language account interacts so frequently with human rights organizations that it has been drawn into the Human Rights and Exiled Opposition cluster) Such activities reflect the MEK's efforts to position itself as an organisation of human rights defenders (users frequently sh describing human ights focused ralles in the diaspora ${ }^{40}$ ). However th are rarely reciprocist and consequenty the MEK cluster is the most desely connected one in our entire network (signaling insularity). (2) Maryam Rajavi

2 2. Follow

The \#Iran ian people are determined to turn this dark page of their history and build a future based on freedom

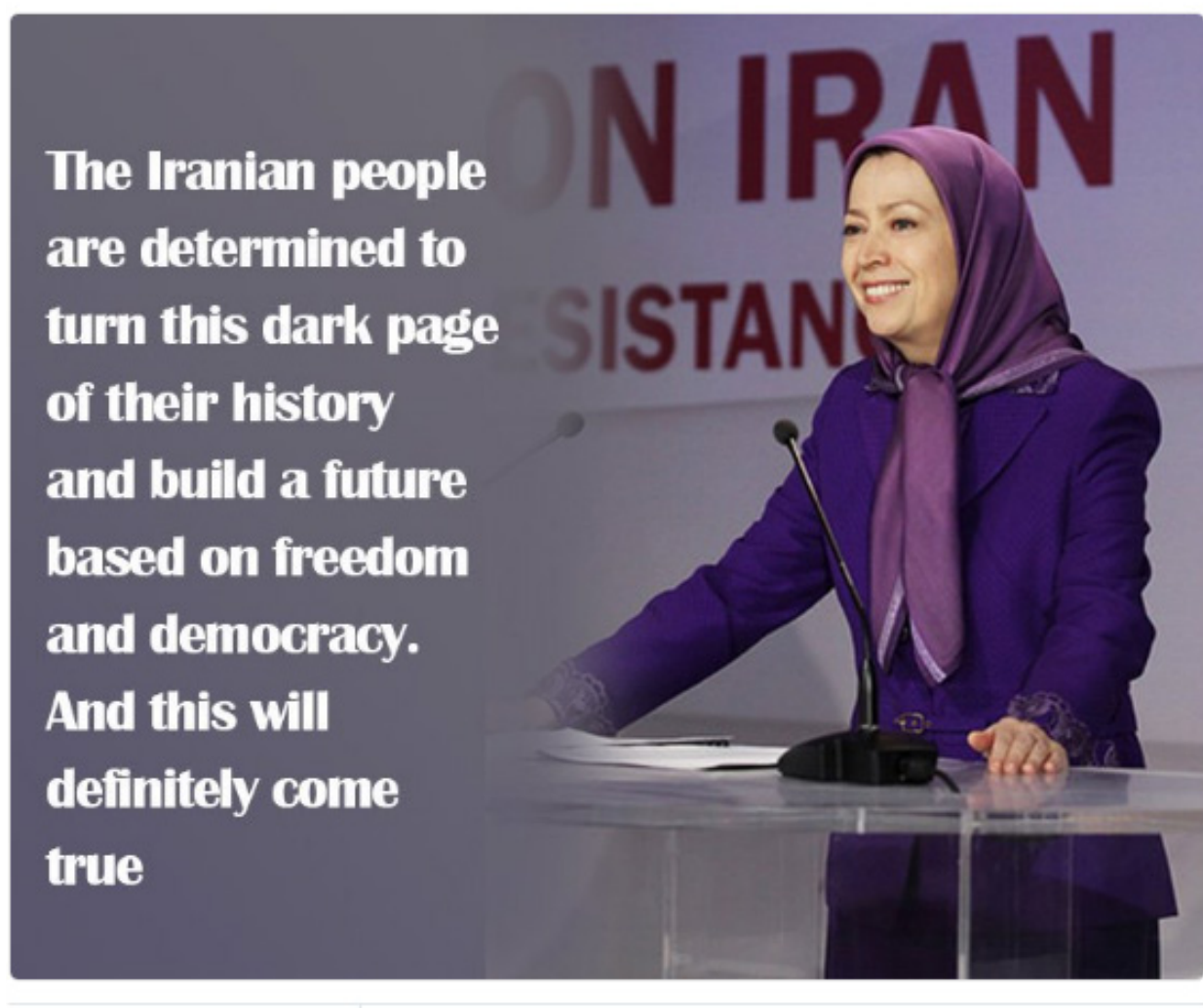

$490 \quad 341$

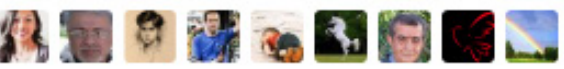

8:07 PM - 20 Feb 2016

Posts by MEK users frequently include pictures of Maryam Rajavi speaking at MEK organized events. These images often contain quotes from her speeches in which she denounces the Islamic Republic, and calls for political change in Iran. Even during the election campaign, few posts commented directly on the elections, and images of Maryam Rajavi remained dominant (see Figure 4.3).

40 National Council of Resistance of Iran, "Supporters of PMOI rally in Sweden for human rights in Iran", 09/29/2015, last accessed: 5/11/2016, http://bitly/MEKHuR 
Reformist Journalists 1

Shargh Journalists

Diaspora Commentariat

Mixed Media Consumers

Diaspora Media 2
Opposition \& Reformist Journalists

Reformist Journalists 2

Diaspora Media 1

Iranian Journalists \& Diaspora

Afghan Media 2

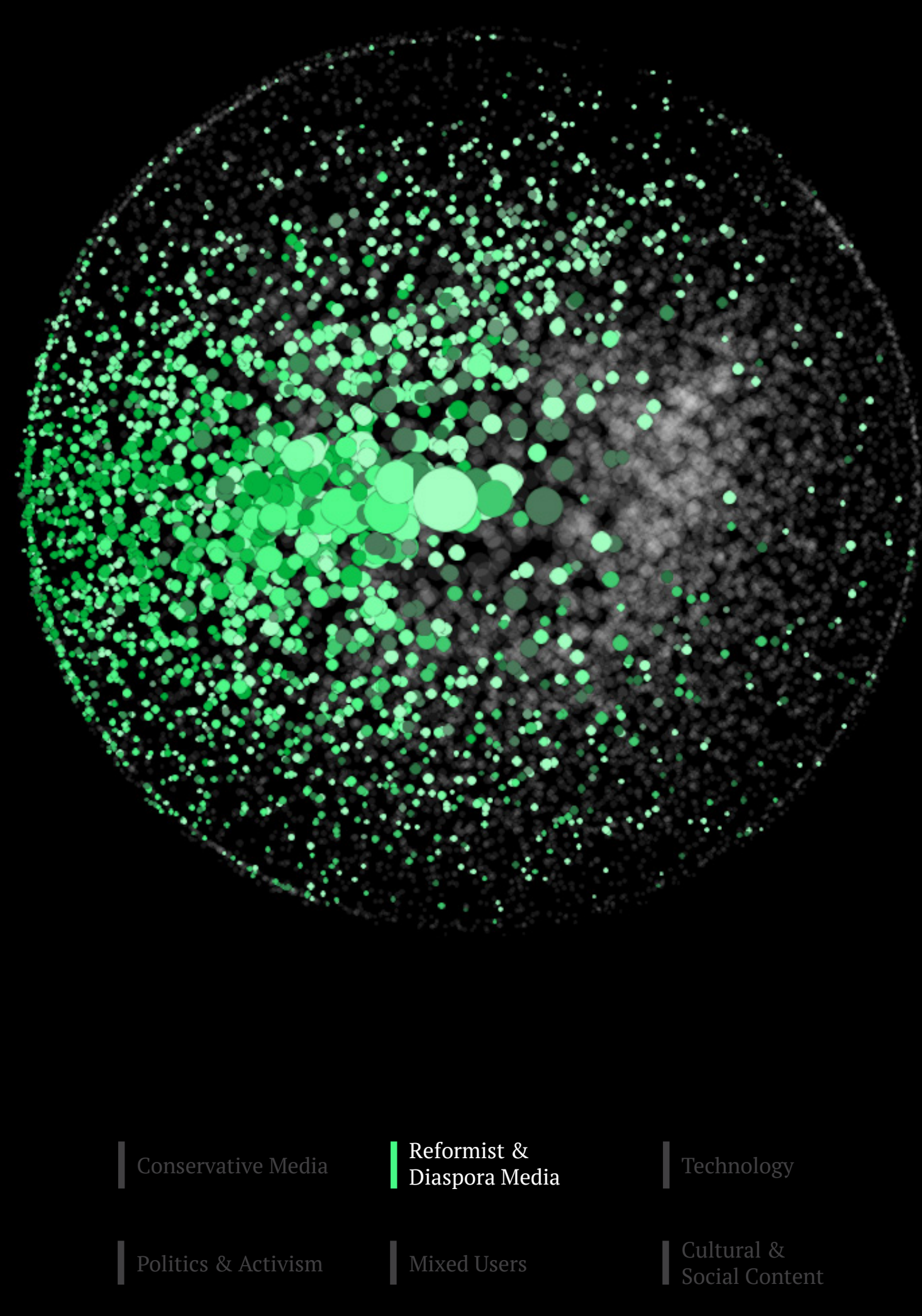

\section{Reformist Journalists \& Diaspora Media}

The Reformist Journalists \& Diaspora Media group and the clusters within it constitute the largest politically focused community in the Iranian Twittersphere, at $21.9 \%$ of the total network. It is largely composed of influential reformist-leaning journalists and media figures (and their followers) from Iran and the wider diaspora. The clusters within this group generally display low levels of density, pointing towards higher levels of connectivity and information exchange between users across different clusters and groups.

Indeed, one of the most striking things about this group is the entangled nature of the networks of diaspora-based and Iran-based journalists. Eight of the clusters in this network contain a majority of accounts based outside Iran, suggesting that Iran's reformist and opposition media ecology is very much global in character. This is not necessarily surprising: many reformist journalists were forced into exile after the 2009 presidential elections but retained networks and professional relationships with journalists continuing to work inside the country.

The cluster demonstrating the highest density rate is the Diaspora Commentariat. This cluster contains a number of high-profile Iranian journalists in the diaspora, including former Voice of America correspondent Negar Mortazavi, Radio Free Europe's Golnaz Esfandiari, Al Monitor's Arash Karami, and The Guardian's Saeed Kamali Dehghan. It also contains a number of reporters from the London-based BBC Persian and Manoto networks. The higher density in this network is suggestive of a relatively tightly knit community of diaspora-based news-shapers and reporters. Al 30 of the most frequently used terms in this cluster were English-language terms, including 'nuclear', implementation,' 'candidates', and 'Zarif', illustrating the political including 'nuclear, 'implementation,' candidates', and 'Zarif, illustrating the political
and geopolitical focus of many users in this cluster, and their largely Western audiences.

Another relatively tight-knit group is Shargh Journalists \& Reformists, which is generally dominated by Shargh journalists including Fatemeh Jamalpour and Asal Abasian, but also includes the accounts of diaspora-based Radio Zamaneh and Turkey-based Iranwire journalist Reza Haghighatnejad. 
Terms most frequently used in this cluster include: 'prisoners,',newspaper,'Ghalibaf' (the Mayor of Tehran), and 'disqualification' (relating to the disqualification of reformist candidates by Iran's Guardian Council prior to the elections), with the vast majority being Persian-language.

The clusters labeled Reformist Journalists are also generally composed of journalists residing inside Iran. Many work for Shargh (including Shabnam Rahmati and Sadra Mohaqeq), though some diaspora figures such as satirist Saman Arbabi and cartoonist Mana Neyestani are also present.

The Diaspora Media clusters are naturally dominated by the official accounts of diaspora-based news agencies such as BBC Persian, Voice of America Persian, and Manoto1. Interestingly, the official account of Foreign Minister Javad Zarif was drawn into this cluster, and sits in essentially the same position as BBC Persian in our network map, suggesting that these accounts exert similar levels of influence over roughly comparable networks. Although these clusters are dominated by influential diaspora-based TV networks, more than half of users in them state that they are located inside Iran (51.9\%), demonstrating diaspora media's influence within the Islamic Republic (this figure is likely to be higher in reality, as many accounts do not share location information).

Discussions in these clusters are broadly political in nature, and focus more on day-to-day political developments when compared to the more human rightsfocused activities of users in the Politics and Activism group. Over the course of the election campaign users in these clusters posted about developments in the race, documented the voting process on election day, and shared results as they came in On voting day, journalist Milad Fadal shared a picture of former political prisone Emad Bahavar meeting the head of Iran's State Prisons Organization in a voting queue in Tehran (see Figure 4.5). A separate post by Mohammad Reza Rostami shared an image of the prominent Iranian poet Hushang Ebtehaj voting for the reformist list on election day (see Figure 4.6). Numerous similar posts came from this segment of the network on election day, as users shared images of highprofile reformist activists, former political prisoners, and public figures casting their ballots, in an effort to encourage higher turnout amongst Iran's reformist voters.

There were widespread fears among reformists that low turnout might boos the chances of a conservative victory. Reformists previously boycotted legislative elections in 2012, resulting in an overwhelming electoral victory for conservatives. Images of respected civil rights activists such as Emad Bahavar and cultural giants like Hushang Ebtehaj supporting reformists in the election lent the race legitimacy among segments of society that might otherwise be hostile to the political institutions and opaque electoral processes of the Islamic Republic.

Reformist Twitter campaigns are covered in greater depth in Chapter 5, where we take a look at some of the turnout-boosting initiatives that were undertaken by reformists on Twitter
A post showing an encounter between a reformist activist and the head of Iran's State Prisons Organization

"A [voting] queue in Hosseiniyeh Ershad, Emad Bahavard meeting his warden, the head of the State Prisons Organizatio Organization
\#election"

[Figure 4.6]

An image of Iranian poet Hushang Ebtehaj voting for the reformist list on election day]

"Hushang Ebtehaj is voting for the reformist list \#election

\section{0.} هاتشخابت ابتهاج در حال راي دادن به فهرست اصلاح طلبان

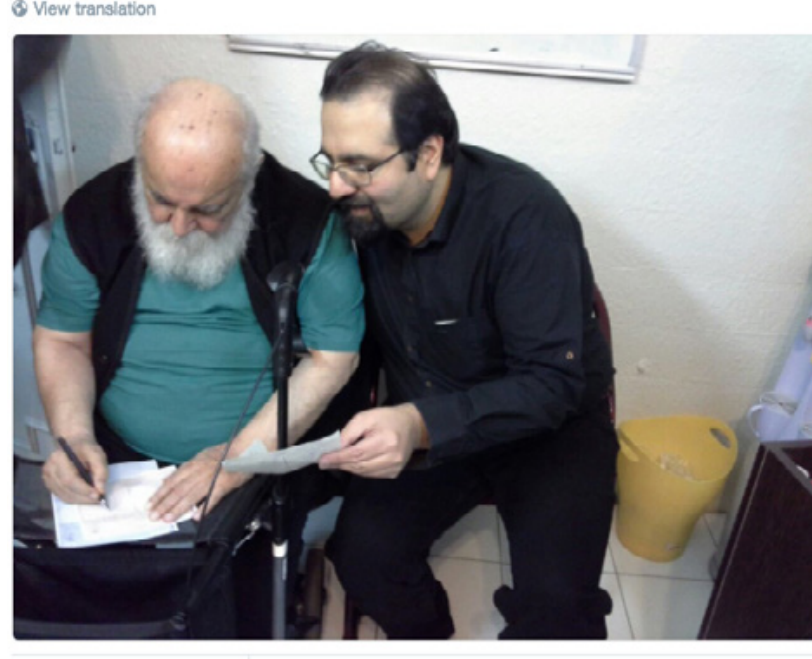
$\begin{array}{ll}\text { Retwerts } & \text { unes } \\ 70 & 390\end{array}$

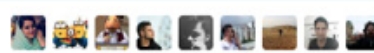

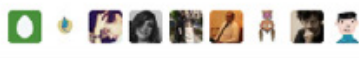




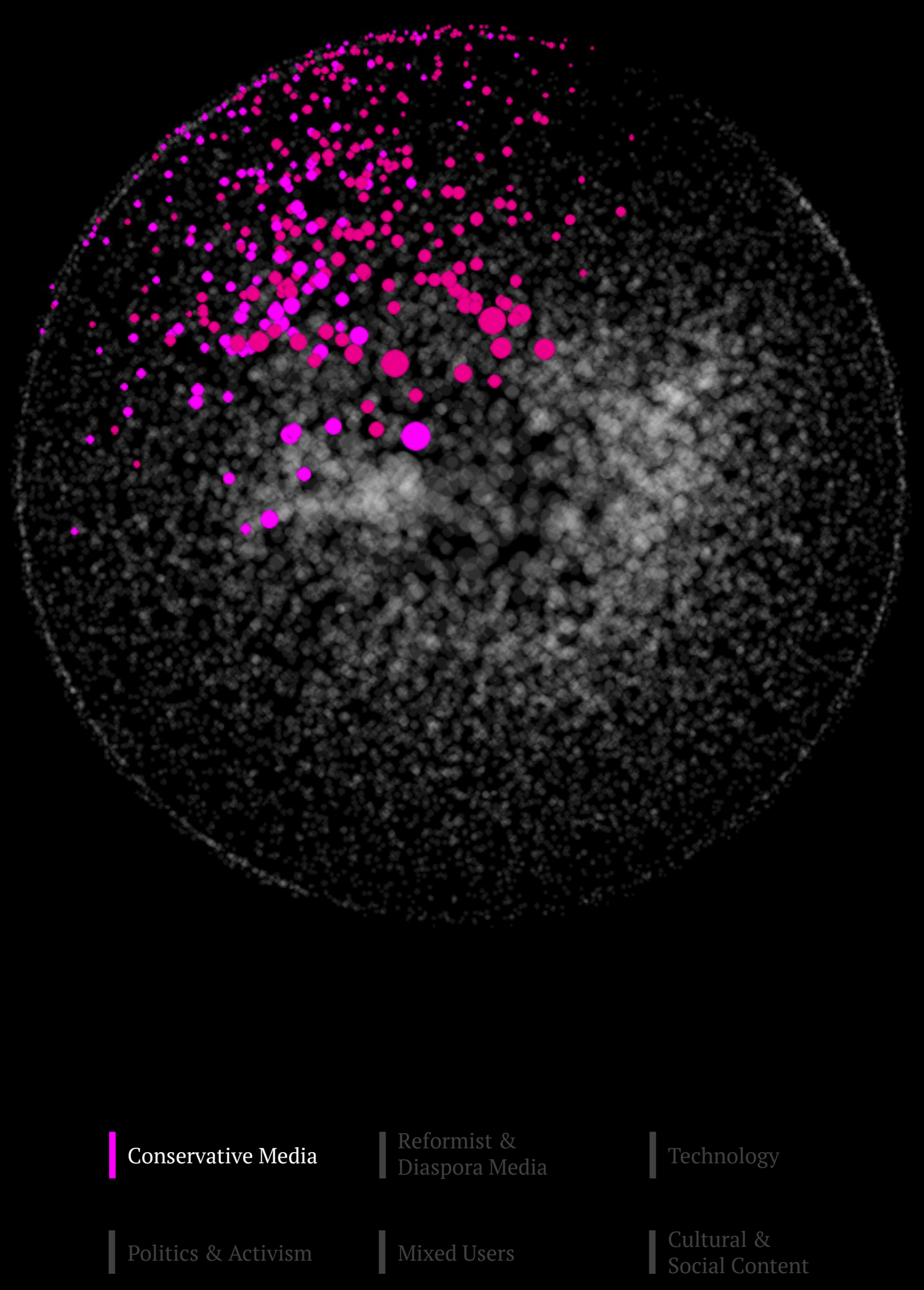

\section{Conservative Media}

The network of conservative journalists and their followers is the smallest within our network, comprising just $3.3 \%$ of the accounts in our network. Compared with reformist and opposition activists, conservative commentators have a somewhat limited presence in the Iranian Twittersphere. Additionally, they are more densely connected than the networks of reformist activists, demonstrating a degree of insularity and isolation from the wider Twitter network.

This isolation is not particularly surprising, and bears out the findings of previous research on this topic. Small Media's 2013 report on conservative online activism'Unmasking the Arzeshi'-suggested that Iran's conservatives rarely took to Twitter, and that their content output on the platform was rather minimal, in preference to other platforms such as domestic SNSs and Google+ (which remains unblocked). ${ }^{41}$ Looking at the extent of conservative activity in this network, it appears that little has changed in this regard, and engagement remains somewhat limited compared to other political communities on Twitter.

Prominent users in the Conservative Media cluster include the blogger Daneshtalab, Editor-in Chief of Farda News Mohammad Saleh Meftah, and Teribon journalist Saeed Sajjad Isfahani. Users in this cluster disproportionately Teribon journalist Saeed Sajjad Isfahani. Users in this cluster disproportionately
link to Google+, along with conservative media outlets Raja News, Al Alam, and Nasim Online. Most frequently used words include religious terms such as 'ijtihad' (independent reasoning), 'jihad', and 'martyr', along with geopolitically focused terms such as 'Saud' and Israel. 
Users in the Clerics and Hardline Media tend towards the domestic SNS Afsaran. ${ }^{42}$ Key information sources for this cluster include the website of the Supreme Leader ${ }^{43}$ and conservative media outlets Fars News, Tasnim News, and Afkar News. Users also frequently link to the religious seminary news service Hawzah News. ${ }^{4}$ Notable users include the cleric Mohsen Lahootian, the religious artist and designe Hossein Samadzadeh, and cleric Ebrahim Nasiri. The most frequently used term by this segment was 'Saud, illustrating the group's focus on the sectarian/geopolitical struggle between Iran and regional nemesis Saudi Arabia. Other common terms includ 'Al Nimr' (the Shi'a leader executed by Saudi Arabia in January 2016), 'martyrdom,'martyrs,' and 'jihad.

Compared with the reformist group, engagement with the elections remained fairly low, though a handful of higher-profile users did post election-related content on a semi-regular basis. Engagement on election day initially started out somewhat hopeful, with users promoting the value of participating in Iran's electoral processes. In this vein, cleric Mohsen Lahootian shared an image of his ballot paper with his followers, explaining his vote for the conservative list (see Figure 4.8). Later in the evening however, as the results began to trickle in, conservatives took to Twitter to express their dismay at the outcome. Conservative journalist Abbas Hosseinejad tweeted in exasperation on election night: "I seek refuge in God at the initial reports!" On February 26 the Iranian electorate delivered a stunning defeat to conservatives. The trend was especially pronounced in Tehran, where conservative political giants such as Mohammad Yazdi and Mohammad-Taqi Mesbah-Yazdi were unceremoniously dumped by the electorate in favor of a coalition of reformists and moderates. ${ }^{45}$

In the face of an active and well-organized reformist online campaign, conservatives attempted to mobilize on Twitter and wage something of a smear campaign against their political opponents (albeit with limited success). Conservative Twitter campaigns are covered in greater depth in Chapter 5.
Mohsen Lahootian shares an image of his ballot paper, with conservative candidates listed

"I voted... for Islam... for the sacred system of the Islamic Republic. for the blood of the for the blood of the
martyrs... for ideas and values... and of course for my selected list."

من رأى دادم...به اسلام...به نظام مقدس جمهورى اسلامى...به خون شهدا...به آرمانها و ارزشها...و البته ليست منتخب خودم... $\checkmark$ View translation

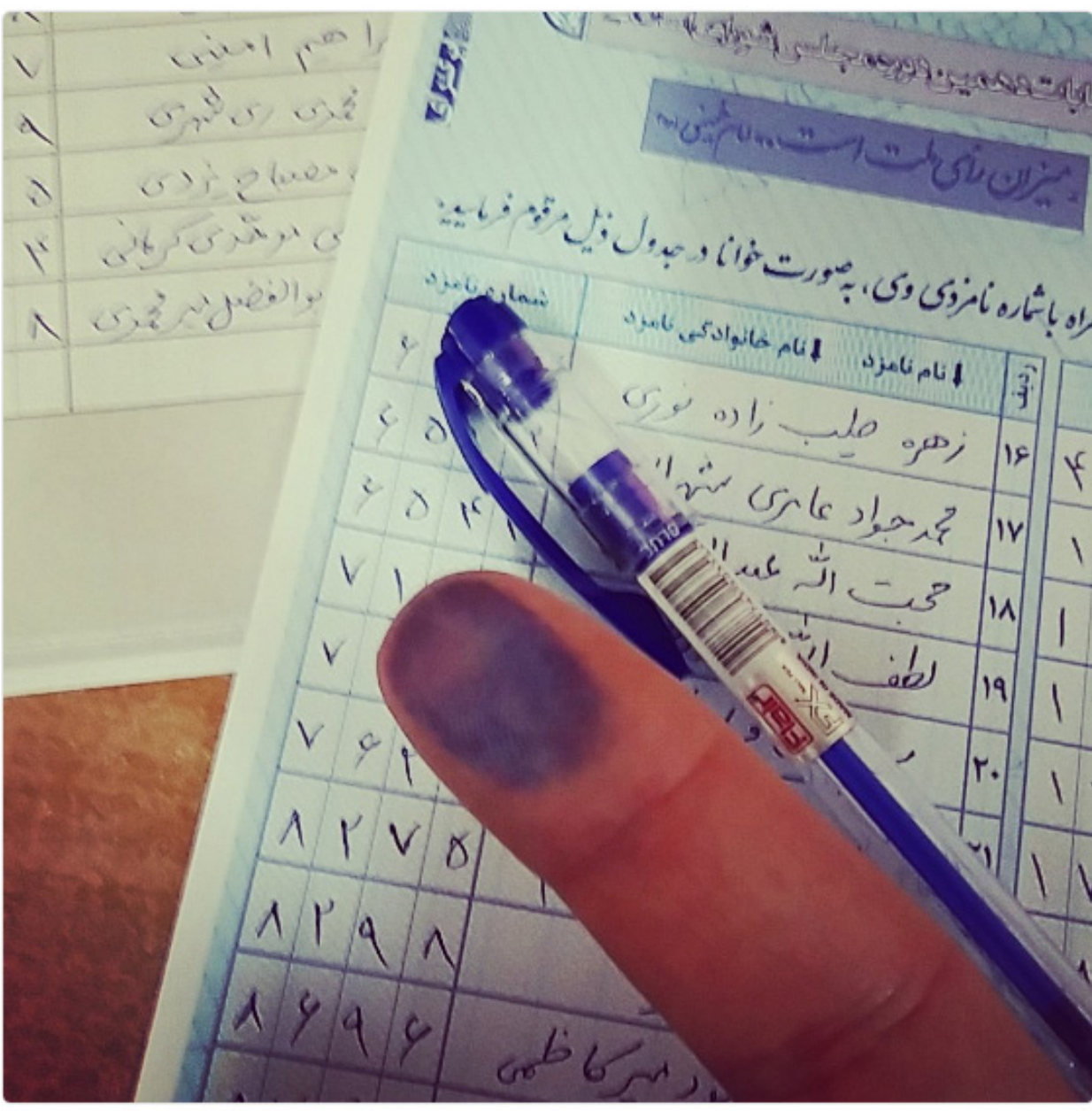

42 Afsaran, last accessed: 5/11/2016, www.afsaran.ir

43 Khamenei.ir, last accessed: 5/11/2016, www.khamenei.it

44 Hawzah News, last accessed: 5/11/2016, www.hawzahnews.com

45 "Iran elections: Reformists make gains in Assembly of Experts", BBC News 02/29/2016, last accessed: 5/11/2016, http:///bit.ly/BBCelex/r 


\section{Technology}

The Iranian tech community has taken to Twitter enthusiastically. This group is comprised of Iranian tech bloggers, entrepreneurs, developers, and start-up gurus, and contains a mixed community of Iran- and diaspora-based users. Interestingly, this group contains the highest proportion of members who publicly identify as living inside Iran, at $72.5 \%$.

Many of the most influential users in this group are located in the Tech Bloggers cluster. Leading users in this cluster include the activist 'Vahid Online,' Nima Akbarpour (the host of BBC Persian's tech show 'Click'), and Nariman Gharib (Manoto's tech correspondent). This cluster's leading figures tend to be diasporabased, although there are a large number of Iran-based users present in the cluster as well.

Also significant within this group are the two clusters labeled Tech Developers. Influential figures in these clusters include software engineer Sallar Kaboli, developer Arash Milani, and web developer Milan Islamizad. Users frequently link to repository hosting service GitHub, along with web development learning platform Sitepoint and location-based SNS Swarm.

The Iranian Entrepreneurs and Iranian Startups clusters largely contain enthusiastic members of Iran's burgeoning tech industry, along with a handful of developers and tech bloggers connected to the sector. Leading voices in this cluster include Avatech founder and startup advocate Mohsen Malayeri, Iran Web Festival founder Shayan Shalileh, and tech blogger 'Jadi'.

The users in the Technology group engaged with the election to some extent, but often through the lens of tech or comedy. There was no great volume of political analysis or commentary within this group, although there was casual engagement with the campaign as it developed, suggesting political awareness if not great amounts of enthusiasm. 
Nima Akbarpour commented little during the election campaign itself, but posted on election night to say "In my opinion the \#results hashtag is about to get hot. We'll track it..." Jadi linked to a blog post in which he argued that people should

engage in more regular acts of political and social engagement, and not attribute sole importance to electoral politics, whereas Mehdi Saharkhiz shared an image

suggesting that Iran's parliamentarians be sent to the 'Recycle Bin' (see Figure 4.10).

\section{[Figure 4.10]}

Mehdi Saharkhiz

shares an image joking

about deleting the

290 members of Iran's

Parliament

"Maybe a restore or two will do it..."

\section{tofy Mehdi Saharkhiz \\ i. @onlymehd}

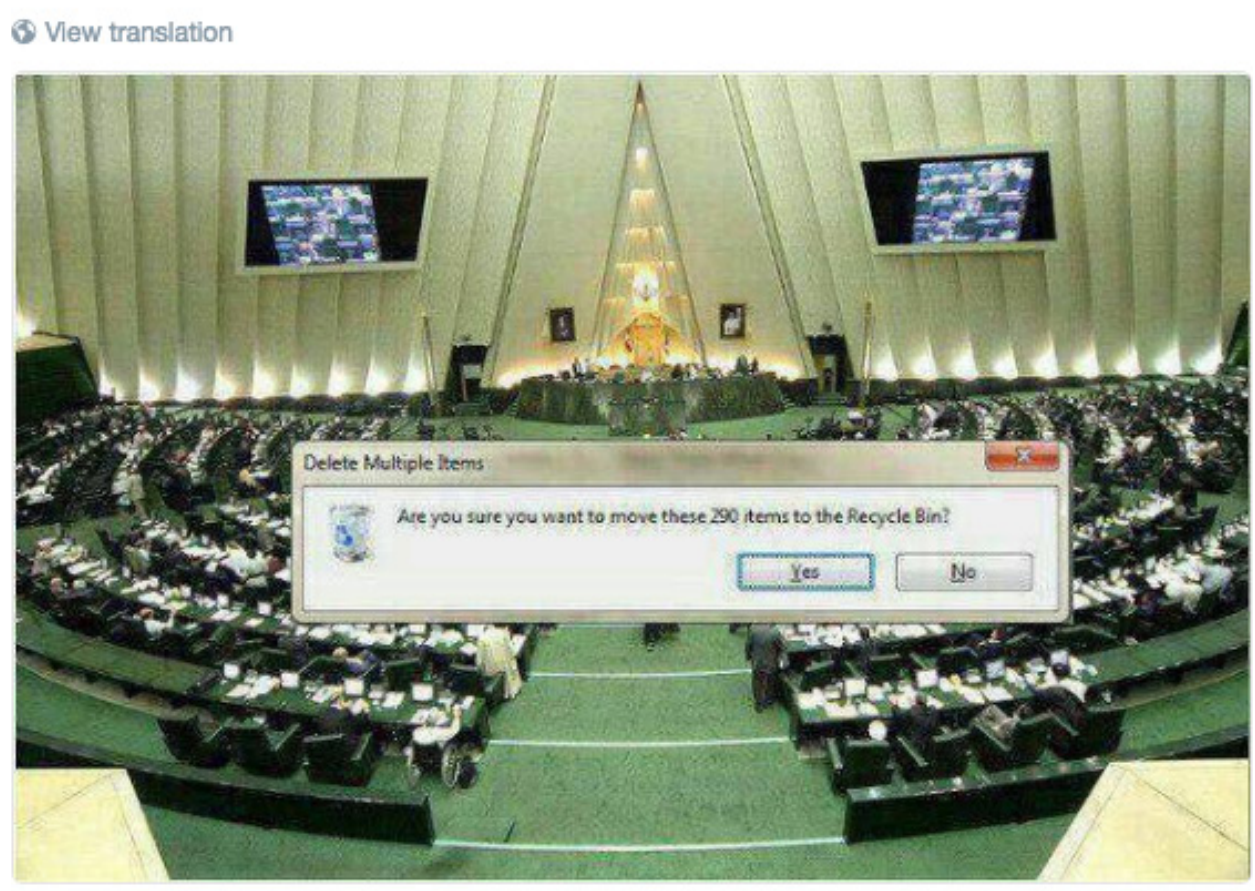

3
50

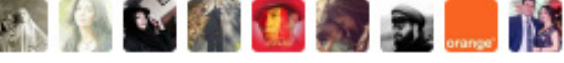

2+ Follow

شايد يكى دوتا ريستور بشن بعد

1:11 PM - 24 Feb 2016 


\section{Literature \& Politics}

Literature 2

Nostalgic Periphery

Social Issues \& Daily Tweets 1

Social Issues \& Daily Tweets 2

Satirists \& Critics

Social Issues \& Daily Tweets 3

Porn Consumers

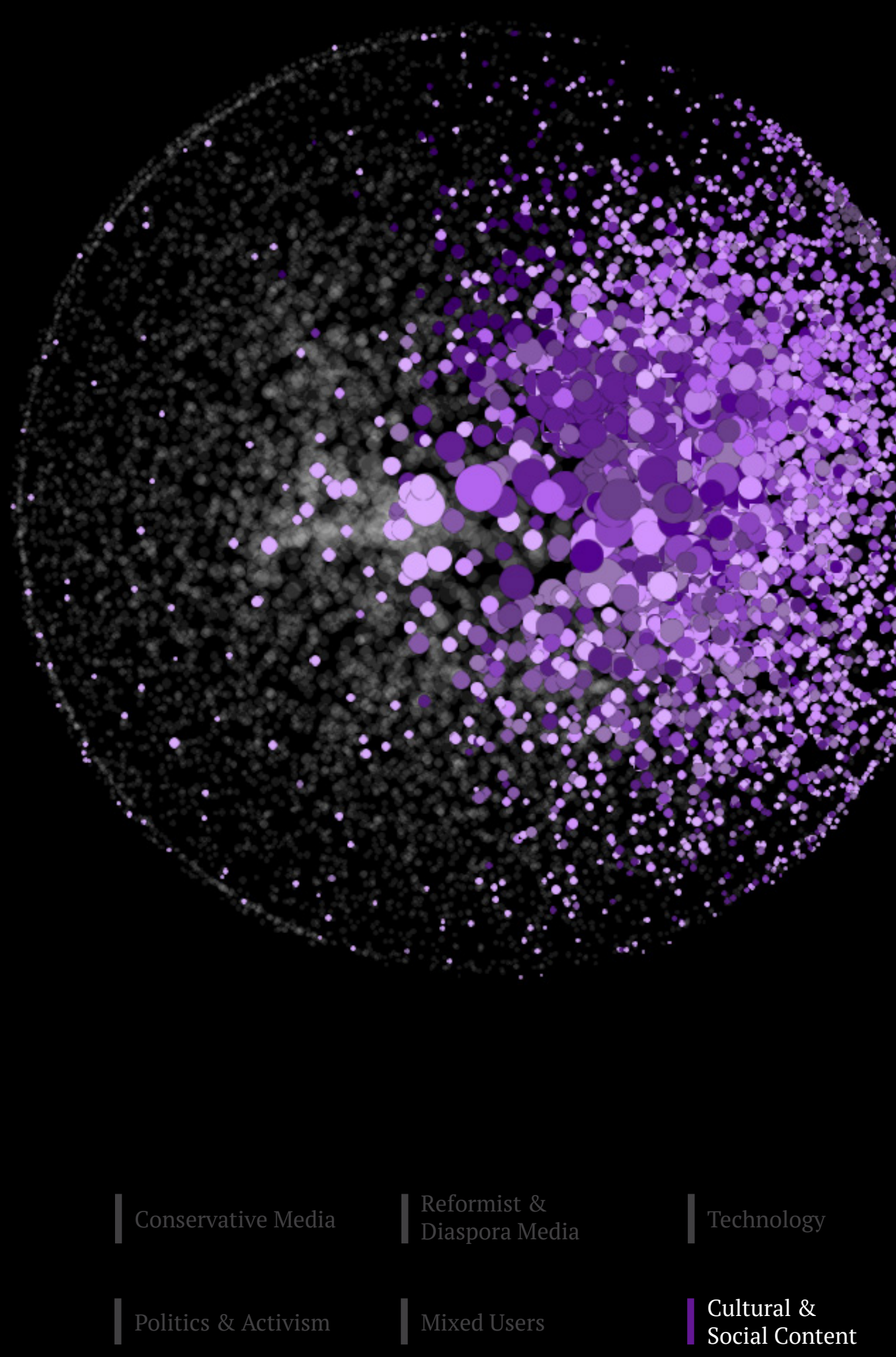

\section{Cultural \& Social Content}

The Berkman Center for Internet \& Society's 2008 appraisal of the Iranian blogosphere revealed a significant segment of bloggers who wrote primarily about Iranian literature, whether sharing their own work or reposting quotes from the country's literary giants. ${ }^{46}$

Based on our appraisal of Iran's Twittersphere, literary content continues to make up a significant chunk of the map-the group of clusters in which users predominantly share Cultural and Social Content is the largest in the network, taking up 36.5\% of the total area. It should be noted that posting and resharing literary content is often just one component of many users' posts - many of the users in these groups also share updates from their daily lives, tweet at their friends, share jokes, and flit with strangers.

Users in the Literature \& Poetry clusters typically alternate between sharing original poetry and quoting the works of Iran's literary giants, from Hafez and Ferdowsi through to modernists like Farrokhzad. Some of this poetic content is political in character although much is not and is posted alongside otherwise banal daly observtions. Although the larger and more infuentiat users in this banal deily observatons.Ath mugh the lary and is posted alo segment post literary content and poetry very regularty (for example, @milads and @Gabr_1989), the majority of other users in this sphere do so relatively infrequently, and also post a variety of political and apolitical content from daily

There is also a very loosely bound cluster of users composed in significant part of Iranian Musicians, including the hip hop artist Hichkas, producer Mahdyar Aghajani, and Iranian music blog Moltafet. These users are distributed all over the Twittersphere, presumably drawn towards clusters containing significant segments of their audiences. 
The Nostalgic Periphery are a cluster of loosely connected users on the edge of the network who largely share social content, although a number of users are also prone to posting historical images of Iran, sweeping landscapes, and (amongst a minority of users) images of the deposed Mohammad Reza Shah. Many of the most influential users in this cluster post very infrequently, and this group is generally quite inactive.

Another cluster in this group is composed of Satirists \& Critics who are openly hostile to the Iranian government. These include users such as MAGNAghermez and ser_serpico. Users in this cluster alternate between discussing popular culture and engaging in heated criticisms of the Iranian establishment posting satirical imases and mocking figures from across the political spectrum. This cluster is ina of the densest in the network, and users within it display higher levels of mutuality tendency than any other cluster in the network. This suggests that the users withi the cluster comprise a tightly knit and generally non-hierarchical community of friends and associates.

One cluster in this group is notable for its remarkably high levels of consumption of pornography. The Porn Consumers cluster disproportionately follows accounts that share pornographic images and videos-they follow primarily English-language accounts, but also a number of accounts that provide Persian-language content. This cluster is not particularly dense, with users scattered throughout the broader group. 
The users in the Mixed Users group
Daily Tweets 1

Daily Tweets 3

Daily Tweets 5

Daily Tweets 7

Daily Tweets 9
Daily Tweets 2

Daily Tweets 4

Daily Tweets 6

Daily Tweets 8

\section{Mixed Users}

This large grouping is a mixture of everyday users, making up $19.2 \%$ of the total network.

The clusters within contain a varied mixture of everyday users, the majority of whom lack strong identifiable characteristics. Users in these clusters post daily observations about their lives, chat with their friends, flirt with strangers, and share humorous videos and images. Although they sometimes engage with topical issues and news events, they are generally less interested in such topics compared to the more overtly political segments of the network. 


\section{Politics \& Acial Content}

\section{Network Structures - Cluster Densities \& Mutuality}

The structure of Twitter clusters can provide some important insights into the nature of the communities studied, as noted by Smith et al's development of six conversational archetypes on Twitter. ${ }^{47}$ We expect to see a variety of different community types within our network, based on differing densities and levels of reciprocity.

Cluster density measures the level of connectivity among nodes in a particular network, and can be calculated as the number of connections between users in a cluster as a proportion of the total possible number of connections. As stated in Smith et al, "The thicker/denser the group, the more people inside it are connected to each other and the less connected they are to people outside their group, ${ }^{48}$ indicating community insularity."

The measurement of mutuality tendency provides evidence for the levels of twoway information exchange and user engagement within a community. We based this measure on Li,Zhang, and Bao's method for assessing cluster-based mutuality tendency, ${ }^{49}$ which calculates how likely the cluster members are to form reciprocal relationships, relative to a random baseline. Values of 0 mean that reciprocal relationships are random chance (the cluster represents a loose association of people with shared interests, e.g., followers of a particular pop star who don't know each other); values close to 1 would mean the relationships are much more likely than random chance (the cluster represents a cohesive community, e.g., a social activism group); and those close to -1 would mean the relationships are much less

47 Marc A. Smith, Lee Rainie, Itai Himelbolm, Ben Schneiderman, “Mapping Twitter Topic Networks: From Polarized Crowds to Community Clusters," Pew Research Center, (2014), last accessed: 5/11/2016, http:///bit.ly/MapTwNet pp. 2-4

48 Ibid p. 6

49 Yanhua Li, Zhi-Li Zhang, Jie Bao, "Mutual or Unrequited Love: Identifying Stable Clusters in Social Networks with Uni- and Bi-directional Links", (2012), last accessed: 5/11/2016, See also: Leo Katz and

choice," Sociometry 18, (1955), pp. 403-409. 
likely than random chance (the cluster is dissociative, e.g., politically divergent groups that pay attention to the same news stories).

\begin{tabular}{|c|c|c|c|}
\hline GROUP & CLUSTER & $\begin{array}{l}\text { CLUSTER } \\
\text { DENSITY }\end{array}$ & $\begin{array}{l}\text { MUTUALITY } \\
\text { TENDENCY }\end{array}$ \\
\hline \multirow{10}{*}{$\begin{array}{l}\text { Reformist \& } \\
\text { Diaspora Media }\end{array}$} & Afghan Media & 0.08 & 0.04 \\
\hline & Diaspora Commentariat & 0.28 & 0.13 \\
\hline & Diaspora Media 1 & 0.01 & 0.00 \\
\hline & Diaspora Media 2 & 0.07 & 0.02 \\
\hline & Iranian Journalists \& Diaspora Media 1 & 0.09 & 0.03 \\
\hline & Mixed Media Consumers & 0.00 & 0.00 \\
\hline & Opposition \& Reformist Journalists & 0.02 & 0.01 \\
\hline & Reformist Journalists 1 & 0.05 & 0.01 \\
\hline & Reformist Journalists 2 & 0.09 & 0.04 \\
\hline & Shargh Journalists & 0.15 & 0.06 \\
\hline \multirow{4}{*}{$\begin{array}{l}\text { Politics \& } \\
\text { Activism }\end{array}$} & Core Influencers & 0.01 & 0.00 \\
\hline & International Human Rights & 0.13 & 0.06 \\
\hline & Mujahedin-e Khalq & 0.55 & 0.38 \\
\hline & Opposition \& Reformist Activists & 0.05 & 0.01 \\
\hline \multirow{6}{*}{ Technology } & Iranian Bloggers & 0.13 & 0.06 \\
\hline & Iranian Entrepreneurs & 0.04 & 0.02 \\
\hline & Iranian Startups & 0.13 & 0.06 \\
\hline & Tech Developer 1 & 0.24 & 0.16 \\
\hline & Tech Developer 2 & 0.18 & 0.08 \\
\hline & Tech Developers \& Bloggers & 0.03 & 0.02 \\
\hline
\end{tabular}

\begin{tabular}{|c|c|c|c|}
\hline \multirow{9}{*}{ Mixed Users } & Daily Tweets 1 & 0.12 & 0.08 \\
\hline & Daily Tweets 2 & 0.10 & 0.04 \\
\hline & Daily Tweets 3 & 0.01 & 0.01 \\
\hline & Daily Tweets 4 & 0.08 & 0.03 \\
\hline & Daily Tweets 5 & 0.09 & 0.07 \\
\hline & Daily Tweets 6 & 0.16 & 0.08 \\
\hline & Daily Tweets 7 & 0.03 & 0.01 \\
\hline & Daily Tweets 8 & 0.29 & 0.20 \\
\hline & Daily Tweets 9 & 0.28 & 0.21 \\
\hline \multirow{15}{*}{\begin{tabular}{|l} 
Cultural \& \\
Social Issues
\end{tabular}} & Iranian Musicians & 0.06 & 0.01 \\
\hline & Literature \& Poetry 1 & 0.07 & 0.04 \\
\hline & Literature \& Poetry 2 & 0.01 & 0.01 \\
\hline & Literature \& Politics & 0.19 & 0.10 \\
\hline & Literature 1 & 0.06 & 0.02 \\
\hline & Literature 2 & 0.18 & 0.15 \\
\hline & Nostalgic Periphery & 0.01 & 0.00 \\
\hline & Poetry & 0.26 & 0.23 \\
\hline & Porn Consumers & 0.01 & 0.00 \\
\hline & Social Issues \& Daily Tweets 1 & 0.17 & 0.14 \\
\hline & Social Issues \& Daily Tweets 2 & 0.13 & 0.11 \\
\hline & Social Issues \& Daily Tweets 3 & 0.11 & 0.07 \\
\hline & Social Issues \& Daily Tweets 4 & 0.10 & 0.04 \\
\hline & Social Issues \& Daily Tweets 5 & 0.05 & 0.01 \\
\hline & Satirists \& Critics & 0.46 & 0.39 \\
\hline \multirow{2}{*}{$\begin{array}{l}\text { Conservative } \\
\text { Media }\end{array}$} & Conservative Journalists & 0.24 & 0.11 \\
\hline & Hardliner Journalists & 0.19 & 0.09 \\
\hline
\end{tabular}


Whole Network

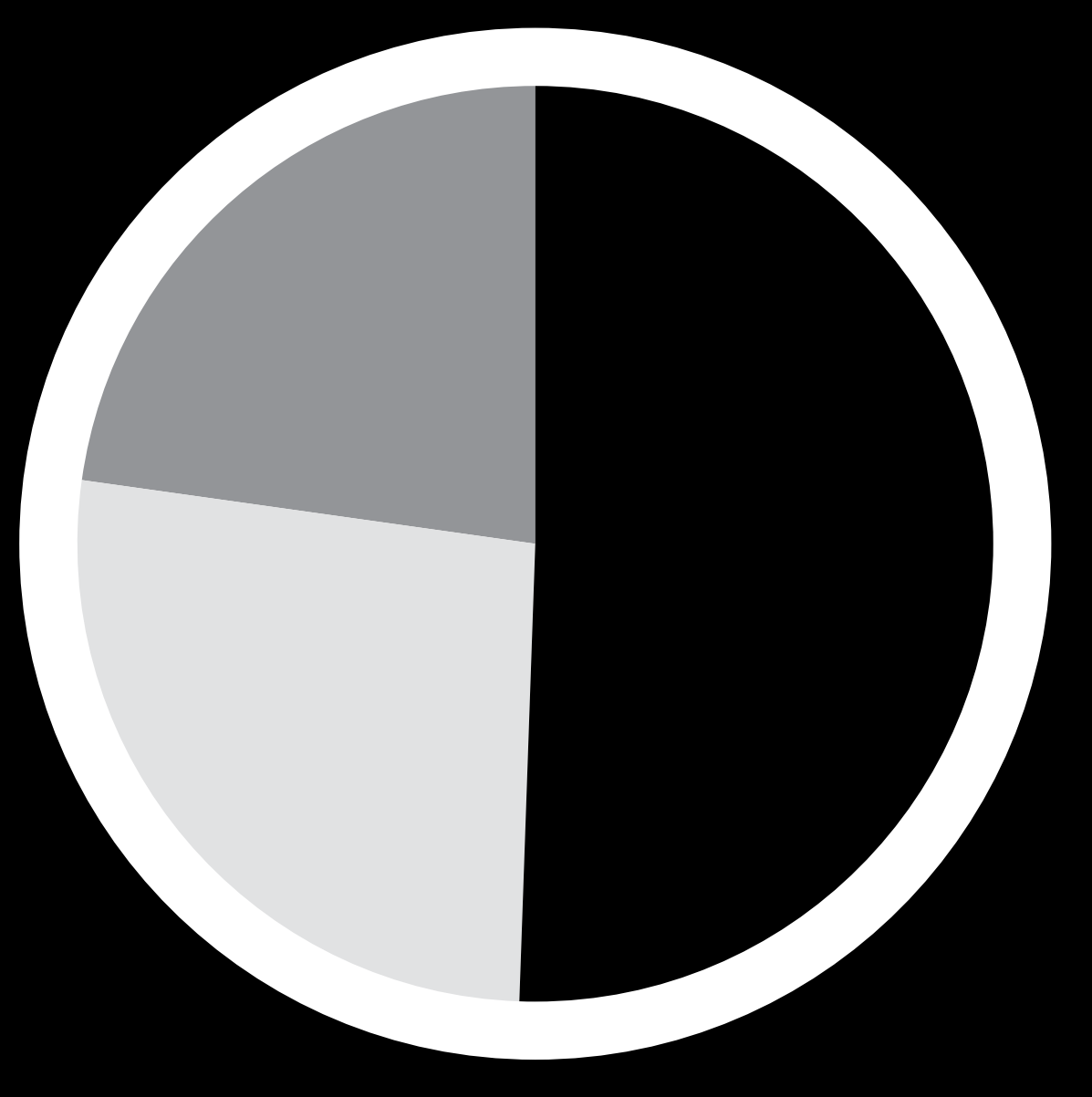

User Locations

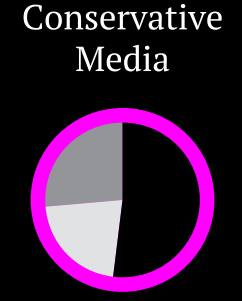

Reformist \&

Technology
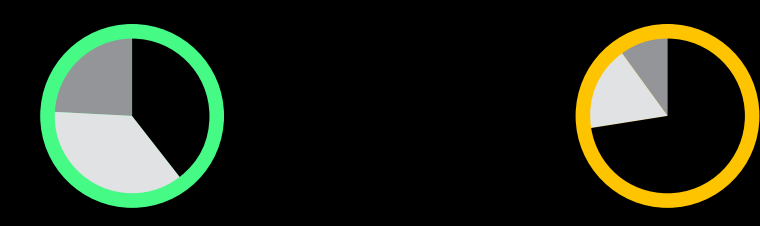

Politics \&

Mixed Users

Cultural \&

\begin{tabular}{|c|c|c|c|}
\hline GROUP & \% INSIDE IRAN & \% OUTSIDE IRAN & $\begin{array}{l}\text { \% UNKNOWN } \\
\text { LOCATION }\end{array}$ \\
\hline $\begin{array}{l}\text { Conservative } \\
\text { Media }\end{array}$ & 52 & 21.8 & 26.1 \\
\hline $\begin{array}{l}\text { Reformist \& } \\
\text { Diaspora Media }\end{array}$ & 39.6 & 36.3 & 24 \\
\hline Technology & 72.5 & 17.5 & 10 \\
\hline $\begin{array}{l}\text { Politics \& } \\
\text { Activism }\end{array}$ & 30.7 & 42.3 & 27 \\
\hline Mixed Users & 59.2 & 25.5 & 15.3 \\
\hline $\begin{array}{l}\text { Cultural \& } \\
\text { Social Content }\end{array}$ & 48.1 & 22.7 & 29.2 \\
\hline Whole Network & 50.7 & 26.7 & 22.6 \\
\hline
\end{tabular}


Gauging the locations of users in our network is a complicated task, and owing to many users' reticence about listing their location publicly, it is impossible to build a complete picture of their distribution around the world. $40.3 \%$ of users are identifiable by the time zone listed in our dataset. For those listing the 'Tehran'

time zone, we applied the tag 'Inside Iran', and for those outside, we applied the tag 'Outside Iran: Then we looking at user-specified location data, which was provided by $48 \%$ of the remaining untagged users in our network. We manually tagged these users based on the information they provided.

After completing this step, we were left with $22.6 \%$ of users who either did not provide any identifying location data, or provided ambiguous information such as 'Somewhere,' Nowhere,' or 'Neverland.' We found that $50.7 \%$ of users stated they lived inside Iran, and $26.7 \%$ stated they lived outside the country.

Users from the Technology group were the most likely to state they lived inside Iran, likely in part stemming from the generally apolitical nature of their activities, and users' interest in building their profile and engaging with the country's growing tech sector. Users from the Politics and Activism and Reformist \& Opposition Media were the least likely to state a location inside Iran, possibly owing to the dangers of engaging in openly political activities and human rights activism in the face of extensive online surveillance. 

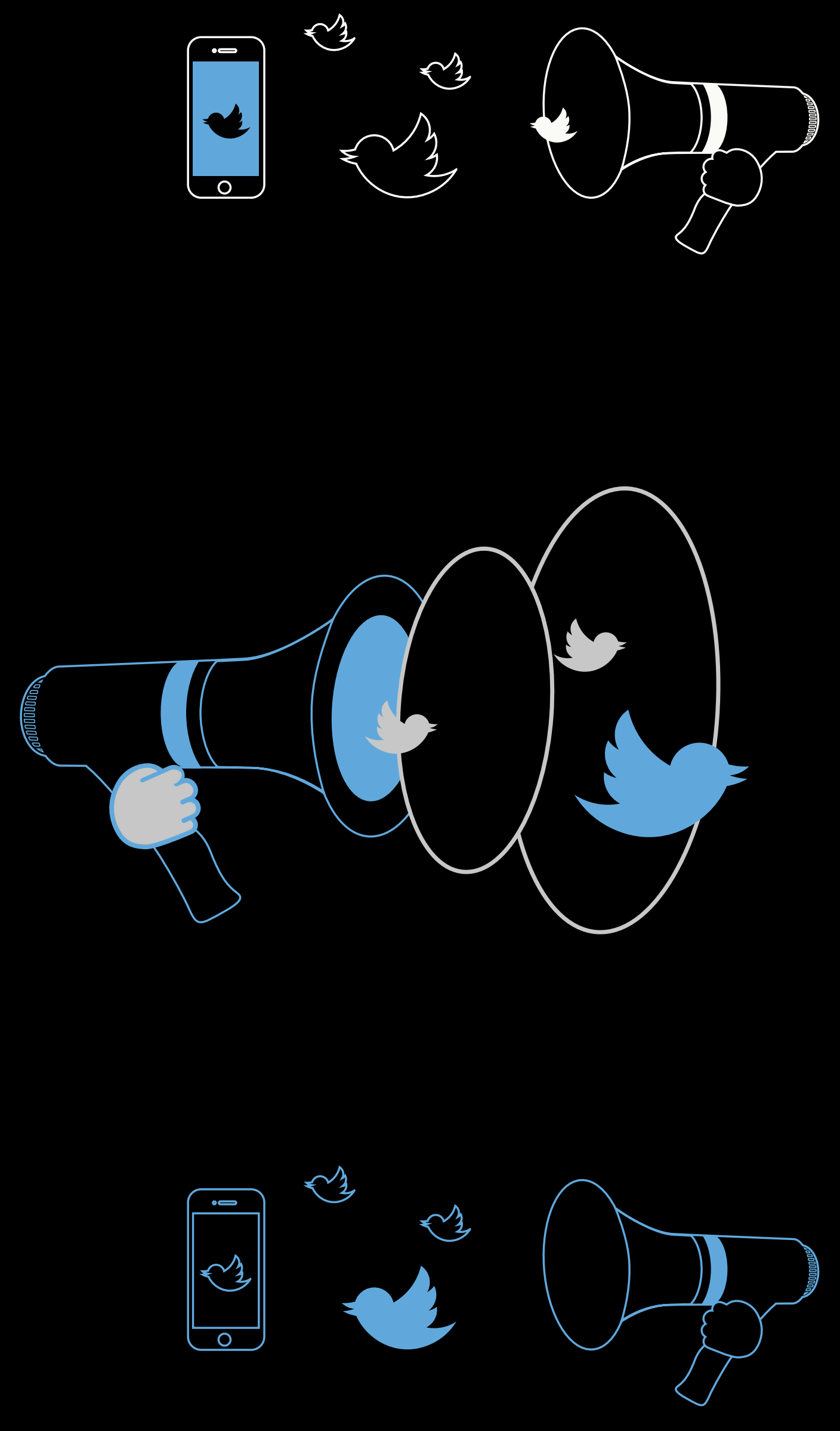

Opinion Shapers - 20 Influential Users

\begin{tabular}{|c|c|c|c|c|}
\hline USER ID & GROUP & $\begin{array}{l}\text { TOTAL } \\
\text { FOLLOWERS }\end{array}$ & $\begin{array}{l}\text { FOLLOWERS } \\
\text { IN } \\
\text { NETWORK }\end{array}$ & USER DESCRIPTION \\
\hline @JZarif & $\begin{array}{l}\text { Reformist } \\
\text { \& Diaspora } \\
\text { Media }\end{array}$ & 381629 & 6224 & $\begin{array}{l}\text { The official Twitter account } \\
\text { of Mohammad Javad Zarif, } \\
\text { Iran's Foreign Minister. He is } \\
\text { close to Hassan Rouhani, is a } \\
\text { political moderate, and is closely } \\
\text { identified with the success of the } \\
\text { Iranian nuclear deal in } 2015 \text {. }\end{array}$ \\
\hline @Vahid & Technology & 81772 & 6178 & $\begin{array}{l}\text { Vahid Online is a high-profile } \\
\text { Iranian cyber activist and citizen } \\
\text { journalist. He is well known due } \\
\text { to his Twitter-based coverage of } \\
\text { the } 2009 \text { presidential elections } \\
\text { and their chaotic aftermath. }\end{array}$ \\
\hline @bbcpersian & $\begin{array}{l}\text { Reformist } \\
\text { \& Diaspora } \\
\text { Media }\end{array}$ & 496886 & 6066 & $\begin{array}{l}\text { The official account of BBC } \\
\text { Persian, the Persian-language } \\
\text { branch of the BBC World Service. } \\
\text { The channel covers national and } \\
\text { international affairs for Persian } \\
\text { speakers around the world. }\end{array}$ \\
\hline @SharghDaily & $\begin{array}{l}\text { Reformist } \\
\text { \& Diaspora } \\
\text { Media }\end{array}$ & 131925 & 5308 & $\begin{array}{l}\text { The official account of the } \\
\text { newspaper Shargh, which is } \\
\text { generally aligned with Iran's } \\
\text { reformists. Shargh was the first } \\
\text { Iranian newspaper to be granted } \\
\text { a verified account on Twitter. }\end{array}$ \\
\hline
\end{tabular}




\begin{tabular}{|c|c|c|c|c|}
\hline @Rouhani_ir & $\begin{array}{l}\text { Politics \& } \\
\text { Activism }\end{array}$ & 221814 & 5086 & $\begin{array}{l}\text { The semi-official account of } \\
\text { Hassan Rouhani (although } \\
\text { President Rouhani has not } \\
\text { confirmed that it belongs to } \\
\text { his office). All tweets on this } \\
\text { account are in Persian. According } \\
\text { to Rouhani, the account is } \\
\text { controlled by his close friends. }\end{array}$ \\
\hline @HassanRouhani & $\begin{array}{l}\text { Politics \& } \\
\text { Activism }\end{array}$ & 438775 & 5084 & $\begin{array}{l}\text { The semi-official English- } \\
\text { language account of President } \\
\text { Hassan Rouhani. President } \\
\text { Rouhani has used this account } \\
\text { to promote Iranian government } \\
\text { policy amongst non-Persian- } \\
\text { speaking audiences, especially } \\
\text { within Western countries. }\end{array}$ \\
\hline @nima & Technology & 89520 & 4967 & $\begin{array}{l}\text { Nima Akbarpour is a BBC Persian } \\
\text { presenter who hosts the tech } \\
\text { slow Click. He is one of the most } \\
\text { famous tech bloggers in Iran, } \\
\text { although he has not actively } \\
\text { blogged for some time. }\end{array}$ \\
\hline @dw_persian & $\begin{array}{l}\text { Politics \& } \\
\text { Activism }\end{array}$ & 247320 & 4438 & $\begin{array}{l}\text { The official Twitter account of } \\
\text { Deutsche Welle in Persian. This } \\
\text { news agency is supported by the } \\
\text { German government. }\end{array}$ \\
\hline @_Cafe & $\begin{array}{l}\text { Politics \& } \\
\text { Activism }\end{array}$ & 44675 & 4148 & $\begin{array}{l}\text { This account is managed by } \\
\text { an anonymous person under } \\
\text { the pseudonym 'Cafe.'The user } \\
\text { frequently criticizes the Iranian } \\
\text { establishment and mocks Iranian } \\
\text { politicians from all parties } \\
\text { (though with an emphasis on } \\
\text { hardliners). }\end{array}$ \\
\hline @ser_serpico & $\begin{array}{l}\text { Cultural } \\
\text { \& Social } \\
\text { Content }\end{array}$ & 23633 & 3799 & $\begin{array}{l}\text { The owner of this account is } \\
\text { anonymous. The user tweets } \\
\text { about various subjects, though } \\
\text { the majority focus on politics } \\
\text { and the economy. }\end{array}$ \\
\hline @BahmanKalbasi & $\begin{array}{l}\text { Reformist } \\
\text { \& Diaspora } \\
\text { Media }\end{array}$ & 71180 & 3529 & $\begin{array}{l}\text { Bahman Kalbasi is the New York } \\
\& \text { UN Correspondent for BBC } \\
\text { Persian. He mostly tweets about } \\
\text { Iran and US politics. }\end{array}$ \\
\hline @VOAIran & $\begin{array}{l}\text { Reformist } \\
\text { \& Diaspora } \\
\text { Media }\end{array}$ & 308339 & 3481 & $\begin{array}{l}\text { The official account of the Voice } \\
\text { of America Persian service, which } \\
\text { is funded by the US government. }\end{array}$ \\
\hline
\end{tabular}

\begin{tabular}{|c|c|c|c|c|}
\hline @RadioFarda_ & $\begin{array}{l}\text { Politics \& } \\
\text { Activism }\end{array}$ & 197036 & 3480 & $\begin{array}{l}\text { The official account of Radio } \\
\text { Farda, the Persian radio station } \\
\text { based in Prague and funded by } \\
\text { the US government. Radio Farda } \\
\text { is a part of Radio Free Europe / } \\
\text { Radio Liberty. }\end{array}$ \\
\hline @holakouee & $\begin{array}{l}\text { Mixed } \\
\text { Users }\end{array}$ & 26065 & 3410 & $\begin{array}{l}\text { The account belongs to Dr. } \\
\text { Farhang Holakouee, an Iranian } \\
\text { sociologist and radio personality } \\
\text { He has a radio program that } \\
\text { offers relationship advice to } \\
\text { callers. }\end{array}$ \\
\hline @amirpaivar & $\begin{array}{l}\text { Reformist } \\
\text { \& Diaspora } \\
\text { Media }\end{array}$ & 65477 & 3300 & $\begin{array}{l}\text { Amir Paivar is the business } \\
\text { correspondent for BBC Persian. } \\
\text { He reported from the Iranian } \\
\text { nuclear talks about the impact } \\
\text { of lifting sanctions and changing } \\
\text { oil prices. }\end{array}$ \\
\hline @sharifi123 & $\begin{array}{l}\text { Mixed } \\
\text { Users }\end{array}$ & 35755 & 3265 & $\begin{array}{l}\text { Ahmad Sharifi is a high-profile } \\
\text { Twitter user who tweets in } \\
\text { Persian, criticizes political and } \\
\text { social norms, and makes fun of } \\
\text { pop culture. }\end{array}$ \\
\hline @NegarMortazavi & $\begin{array}{l}\text { Reformist } \\
\text { \& Diaspora } \\
\text { Media }\end{array}$ & 87920 & 3259 & $\begin{array}{l}\text { Negar Mortazavi is a former host } \\
\text { at VOA Persian and currently } \\
\text { works as a freelance journalist } \\
\text { and analyst based in New York } \\
\text { City. }\end{array}$ \\
\hline @AlanEyre1 & $\begin{array}{l}\text { Reformist } \\
\text { \& Diaspora } \\
\text { Media }\end{array}$ & 70252 & 3204 & $\begin{array}{l}\text { Alan Eyre is the Persian- } \\
\text { language spokesperson for } \\
\text { the US State Department. He } \\
\text { actively promotes US policy } \\
\text { relating to Iran to Iranians, with } \\
\text { a focus on those living inside } \\
\text { Iran. }\end{array}$ \\
\hline @USAdarFarsi & $\begin{array}{l}\text { Politics \& } \\
\text { Activism }\end{array}$ & 153809 & 3178 & $\begin{array}{l}\text { The official Persian-language } \\
\text { Twitter account of the US State } \\
\text { Department. }\end{array}$ \\
\hline @MAGNAghermez & $\begin{array}{l}\text { Cultural } \\
\& \text { Social } \\
\text { Content }\end{array}$ & 16547 & 3158 & $\begin{array}{l}\text { The user is anonymous, and } \\
\text { most of his tweets express his } \\
\text { hostility to the regime. He mocks } \\
\text { the Iranian political system, } \\
\text { along with assorted other public } \\
\text { figures and celebrities. }\end{array}$ \\
\hline
\end{tabular}


The majority of the top 20 users in our network originate from politically focused networks -14 users are located in the Politics \& Activism and Reformist \&

Opposition Media clusters. Notably, none of the top users in our network are

members of the Conservative Media cluster, nor do any prominent conservative

politicians feature in this top set (Supreme Leader Khamenei-the highest-ranked

conservative politician in our dataset-only managed 31st place. The top-ranked

user from the Conservative Media cluster attained 517th place overall).

These rankings once again demonstrate the disproportionate influence of

reformist-leaning political activists, journalists, and human rights activists in the

Iranian Twittersphere. Only one user in this list-Dr. Farhang Holakouee-posts

content that is consistently apolitical in nature. 


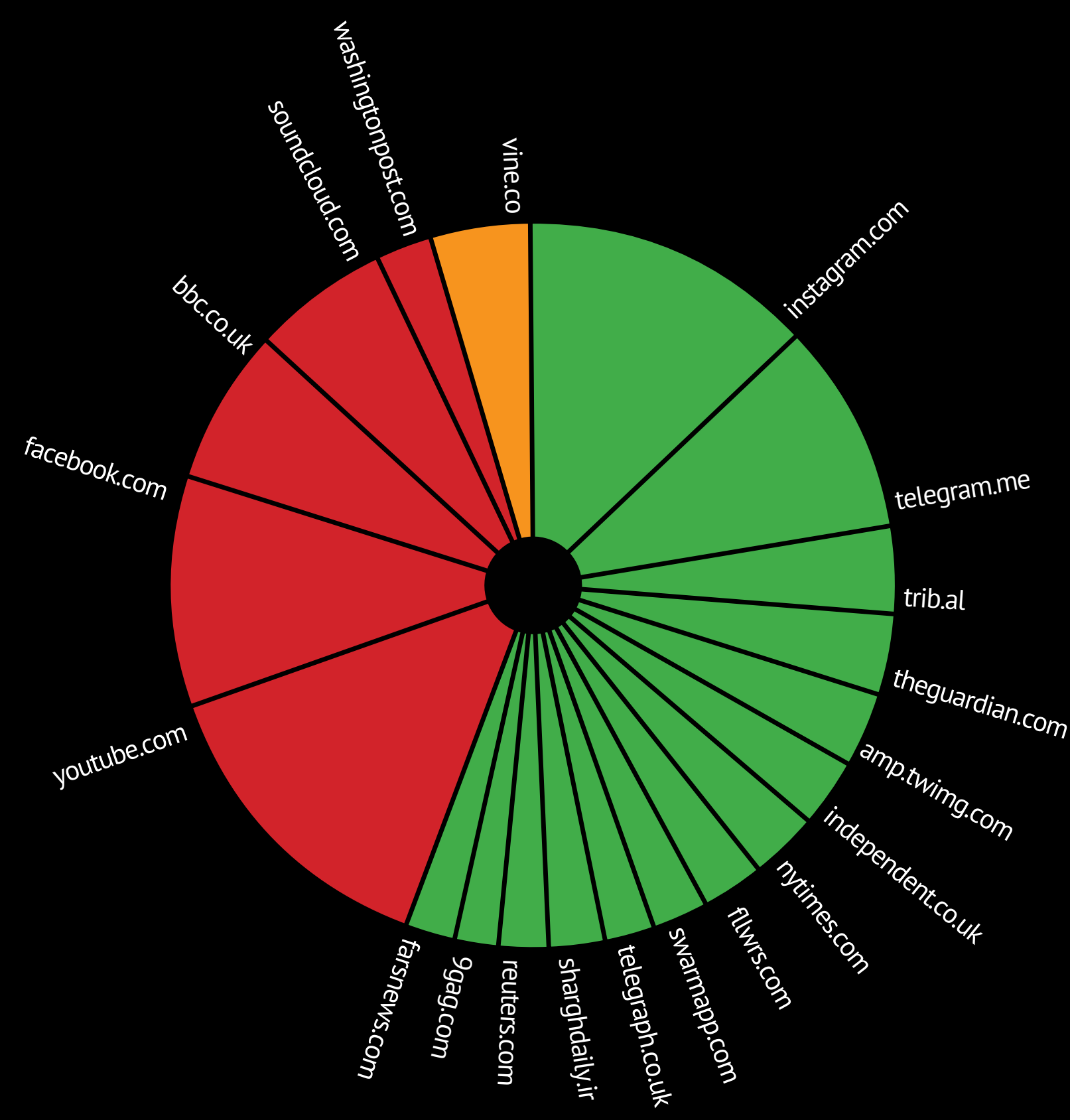

X BLOCKED

NOT BLoCKED

? UNKNOWN

Information Sources - Top 20 Links

\begin{tabular}{|c|c|c|}
\hline LINK URL & $\begin{array}{l}\text { LINKS IN } \\
\text { NETWORK }\end{array}$ & DESCRIPTION \\
\hline youtube.com & 1826 & $\begin{array}{l}\text { Despite being blocked in Iran, the video sharing } \\
\text { platform remains the most widely linked-to website } \\
\text { in our network. } \\
\text { YouTube played an important role in the Iranian } \\
\text { parliamentary elections when former President } \\
\text { Khatami posted a video inviting voters to support } \\
\text { the 'List of Hope.' }\end{array}$ \\
\hline instagram.com & 1723 & $\begin{array}{l}\text { Instagram is a popular image sharing and social } \\
\text { networking site that remains unblocked in Iran. } \\
\text { Consequently, it is used by a wide range of Iranian } \\
\text { politicians, public figures, and citizens, including } \\
\text { President Hassan Rouhani, Supreme Leader } \\
\text { Khamenei, and Foreign Minister Javad Zarif. }\end{array}$ \\
\hline facebook.com & 1350 & $\begin{array}{l}\text { With estimates of usage in Iran ranging from } \\
\text { between } 6 \text { to } 27 \text { million users, } 2>\text { Facebook remains } \\
\text { the most popular social network in the country, } \\
\text { despite the government's attempts to block it. } \\
\text { Despite Facebook being censored, Iranian politicians } \\
\text { including Supreme Leader Khamenei and Foreign } \\
\text { Minister Zarif maintain accounts. }\end{array}$ \\
\hline
\end{tabular}




\begin{tabular}{|c|c|c|}
\hline telegram.me & 1239 & $\begin{array}{l}\text { Telegram is the most popular communication } \\
\text { mobile app in Iran. According to official statistics, it } \\
\text { has around } 20 \text { million users in the country. } \\
\text { Telegram is the first non-Iranian mobile app that } \\
\text { has been promoted by Iranian state television. }\end{array}$ \\
\hline bbc.co.uk & 893 & $\begin{array}{l}\text { The Iranian government takes an aggressive stance } \\
\text { against the BBC, blocking access to its website and } \\
\text { jamming satellite broadcasts of the BBC Persian } \\
\text { Service. }\end{array}$ \\
\hline soundcloud.com & 775 & $\begin{array}{l}\text { SoundCloud is blocked in Iran although it is } \\
\text { popular amongst Iranian musicians and producers- } \\
\text { especially underground rappers and musicians. }\end{array}$ \\
\hline vine.co & 565 & $\begin{array}{l}\text { Vine is somewhat popular amongst Iranians, } \\
\text { although there are conflicting reports about } \\
\text { whether the platform is blocked or not. } \\
\text { People can upload short videos on Vine and share } \\
\text { them amongst their networks. }\end{array}$ \\
\hline trib.al & 496 & $\begin{array}{l}\text { Trib.al is a link shortening and advanced analytics } \\
\text { service popular amongst Twitter users. }\end{array}$ \\
\hline theguardian.com & 479 & $\begin{array}{l}\text { The Guardian is a leading UK newspaper that } \\
\text { is a particularly popular news source amongst } \\
\text { moderates and reformists in Iran. It is not blocked. } \\
\text { Its Iran coverage includes Tehran Bureau-an } \\
\text { online news magazine covering cultural, social, } \\
\text { and political issues in Iran, written by anonymous } \\
\text { in-country correspondents. It is edited by Golnoush } \\
\text { Niknejad. }\end{array}$ \\
\hline amp.twimg.com & 433 & Twitter's image hosting service. \\
\hline independent.co.uk & 384 & $\begin{array}{l}\text { The Independent is a leading British newspaper } \\
\text { that is unblocked in Iran. Iranian media agencies } \\
\text { frequently use The Independent as a source in their } \\
\text { reporting. }\end{array}$ \\
\hline nytimes.com & 393 & $\begin{array}{l}\text { The New York Times is a US-based and globally } \\
\text { influential newspaper that is unblocked in Iran. } \\
\text { Iranian politicians have previously published } \\
\text { articles in this newspaper, including Iranian Foreign } \\
\text { Minister Javad Zarif. }\end{array}$ \\
\hline fllwrs.com & 373 & $\begin{array}{l}\text { Fllwrs is a Twitter follower tracker which is very } \\
\text { popular amongst Iranian users. Fllwrs tells users } \\
\text { how many users follow (or unfollow) them. }\end{array}$ \\
\hline
\end{tabular}

\begin{tabular}{|c|c|c|}
\hline washingtonpost.com & 338 & $\begin{array}{l}\text { Despite the Washington Post being blocked in Iran, } \\
\text { Iranian officials such as President Hassan Rouhani } \\
\text { have published articles in this US paper. }\end{array}$ \\
\hline swarmapp.com & 306 & $\begin{array}{l}\text { Swarm is a check-in app developed by Foursquare. } \\
\text { This app is popular amongst Iranians and they use } \\
\text { it to check in and share their location with their } \\
\text { network. }\end{array}$ \\
\hline telegraph.co.uk & 297 & $\begin{array}{l}\text { The Telegraph is a British newspaper which is } \\
\text { unblocked in Iran. This newspaper has been used as } \\
\text { a source for various reports in the Iranian media. }\end{array}$ \\
\hline sharghdaily.ir & 330 & $\begin{array}{l}\text { Shargh is a reformist newspaper that has been } \\
\text { closed by authorities a number of times in recent } \\
\text { years-in 2004, 2006, } 2007 \text { and most recently in } \\
2012 \text {. } \\
\text { The newspaper resumed activity in } 2013 \text {, and is } \\
\text { published on a daily basis. Shargh has an active } \\
\text { Twitter account. }\end{array}$ \\
\hline reuters.com & 276 & $\begin{array}{l}\text { Reuters is an international news agency with a } \\
\text { bureau in Tehran. The website is unblocked and } \\
\text { accessible inside Iran. }\end{array}$ \\
\hline 9gag.com & 253 & $\begin{array}{l}9 \text { GAG is a joke and image sharing platform popular } \\
\text { amongst Iranian Twitter users. }\end{array}$ \\
\hline farsnews.com & 284 & $\begin{array}{l}\text { Fars News Agency is a hardline conservative news } \\
\text { agency which is politically close to the Iranian } \\
\text { Revolutionary Guard Corps (IRGC), generally } \\
\text { promoting conservative and hardline policy. }\end{array}$ \\
\hline
\end{tabular}

The most linked-to media sources in our network are alternative SNSs, demonstrating the interconnected nature of Iran's social media ecology. YouTube, Facebook, Instagram, Vine, Soundcloud, and Swarm all feature prominently, although a number of these platforms are blocked. Notable by their absence are Iran's domestically developed social media platforms, such as Facenama or Afsaran, Instagram analogue Lenzor, or the Iranian version of YouTube, named Aparat. Although the Iranian government has a long track record of filtering internationally developed SNSs in order to push users towards Iran-hosted (and thus more easily surveilled) alternatives ${ }^{50}$ such efforts appear to have made little headway within this network. (Of course, the Iran-based users in this network are already users of circumvention tools-otherwise they wouldn't be able to access Twitter in the first place.) 
Also notable in these rankings is the significance of international media sources for Iranian users. Shargh (reformist newspaper) and Fars News (conservative news agency) are the only two Iranian outlets to make the top rankings. This is against seven international news outlets and newspapers ranging from the $B B C$, to The Guardian, through to Reuters. What is also interesting is that so few of these news sources are censored by the Iranian government-the Washington Post and BBC are the only two to be blocked. Given that the other Western media sources in this list frequently criticize Iran's human rights record and lack of political freedoms, the

blocks imposed on certain outlets do appear to be somewhat arbitrary.

The arbitrary nature of censorship is reflected in the blocking of SNSs and

communications services. Although Instagram and Telegram are home to a variety

of users and groups critical of the Islamic Republic, and to sexual content and other content deemed unacceptable to the Iranian authorities, they remain unblocked,

while Facebook, YouTube, and Twitter are censored. Regardless, among this network

the state's efforts appear to have a minimal effect on user behaviors -Facebook and

YouTube remain the most influential information sources in the network. 


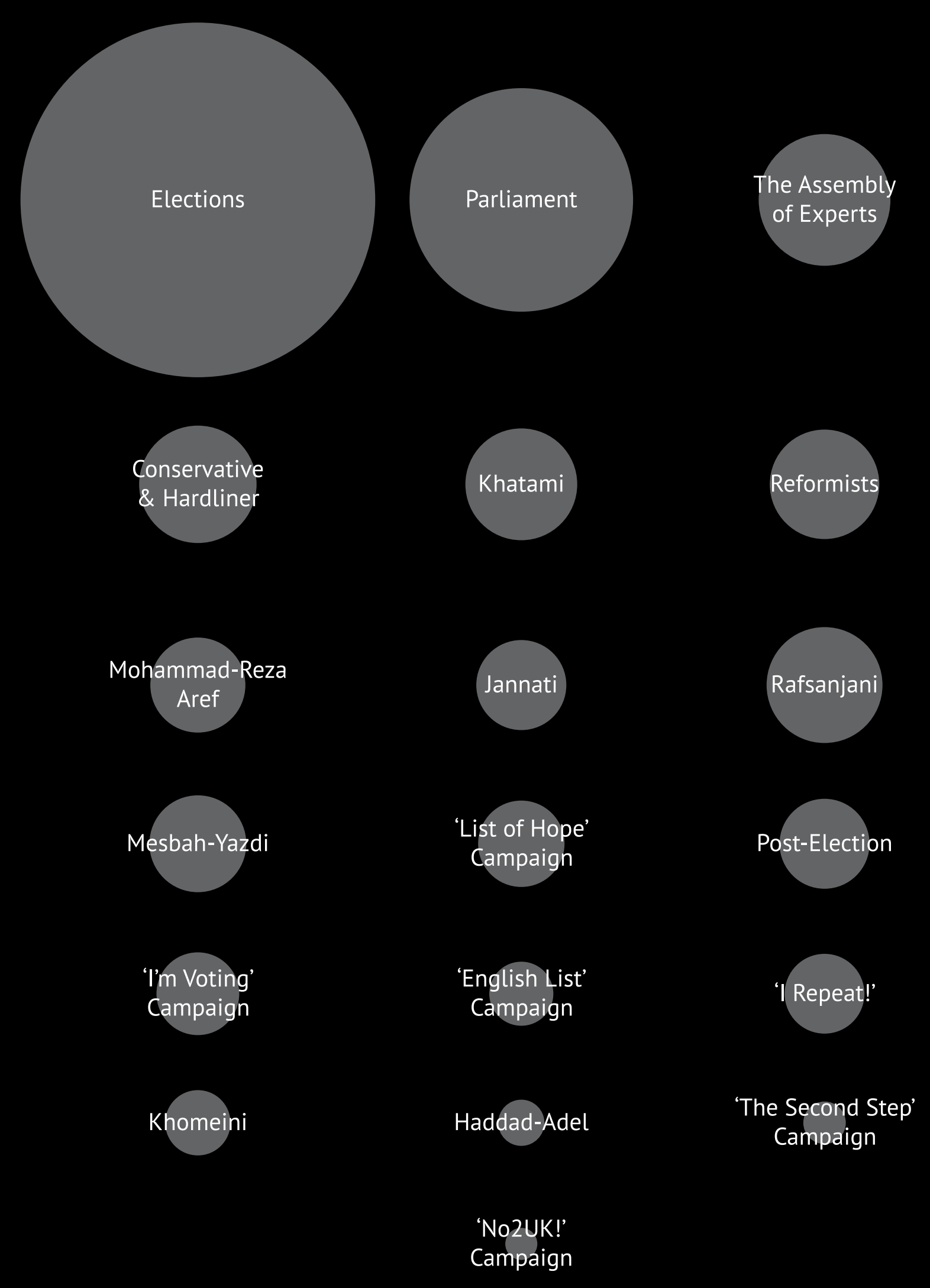




\section{Election Tweeting - An Overview}

\begin{tabular}{|c|c|c|c|}
\hline RANK & TERMS & UNIQUE USERS & TOTAL TWEETS \\
\hline 1 & Elections & 3300 & 74391 \\
\hline 2 & Parliament & 2149 & 29547 \\
\hline 3 & The Assembly of Experts & 1230 & 10258 \\
\hline 4 & Conservative \& Hardliner & 1134 & 8150 \\
\hline 5 & Khatami & 1069 & 7393 \\
\hline 6 & Reformists & 964 & 7086 \\
\hline 7 & Mohammad-Reza Aref & 944 & 5340 \\
\hline 8 & Jannati & 814 & 4792 \\
\hline 9 & Rafsanjani & 806 & 7940 \\
\hline 10 & Mesbah-Yazdi & 733 & 5548 \\
\hline 11 & 'List of Hope' Campaign & 714 & 4411 \\
\hline 12 & Post-Election & 600 & 4784 \\
\hline 13 & 'I'm Voting' Campaign & 589 & 4050 \\
\hline 14 & 'English List' Campaign & 505 & 2426 \\
\hline 15 & ‘I Repeat!’ & 500 & 3763 \\
\hline 16 & Khomeini & 358 & 2519 \\
\hline 17 & Haddad-Adel & 323 & 1261 \\
\hline 18 & 'The Second Step' Campaign & 195 & 1067 \\
\hline 19 & ‘No2UK!' Campaign & 57 & 607 \\
\hline
\end{tabular}

For the purposes of this study, we tested 19 terms related to the recent elections, including generic terms, politicians' names, and high-profile online campaigns. We recorded the frequency with which any of these terms were mentioned by network members between February 18-29, 2016-a period spanning the official election campaign and the immediate aftermath of the February 26 elections.

The most striking initial impression is that the most frequently cited terms are related to generic terms, or terms directly related to newsworthy figures, suggesting that that most common election-related activities were related to general discussion around the unfolding events of the election campaign. Specific, action-oriented social media campaigns such as the 'List of Hope' and 'I'm Voting' campaigns proved relatively popular (particularly among reformist-leaning segments of our map), but were not as widely discussed as figures such as Khatami Jannati, and Aref.

Twitter users engaged with a number of online campaigns in an effort to influence the outcome of the vote. In the following section we'll profile five high-profile campaigns that took off over the course of the election campaign, examining their effectiveness, their reach, and their target audiences.

The most significant trend we can identify is that reformist-oriented campaigns are far more widely shared and effective than their conservative counterparts. Reformist campaigns had clearer objectives, were implemented strategically, and were executed professionally. Conservative efforts were far more reactive to events, and never really managed to set the agenda on Twitter. 
Users mentioning 'List of Hope

February 18-29, 2016

Terms:

ليست اميد

\section{Campaign 1: The List of Hope}

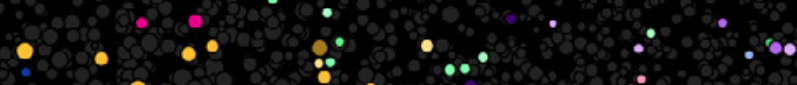
$2: 00 \% \circ \%$ 800380.90 $\because 0080$ 0.000000

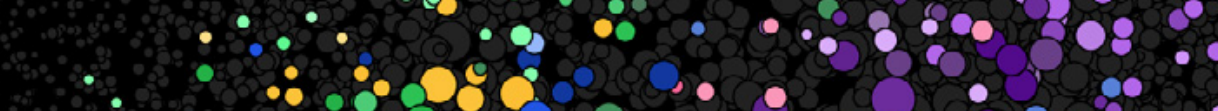

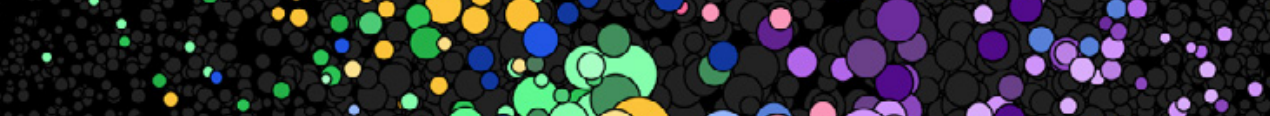

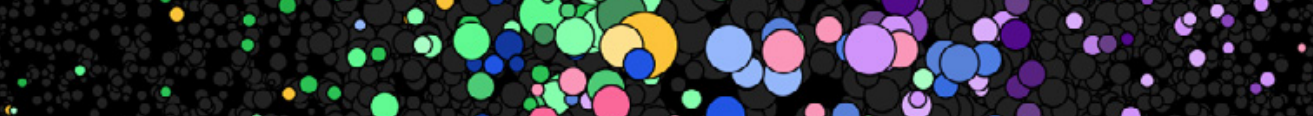

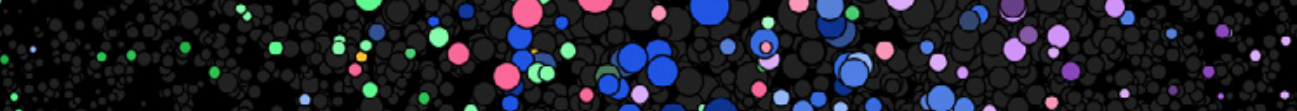

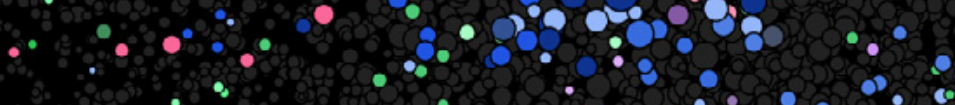

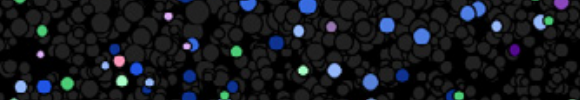
.

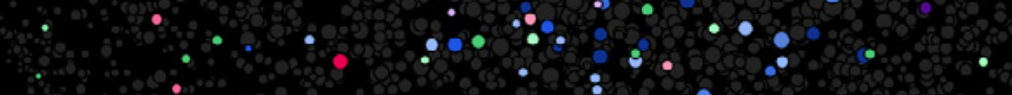

\begin{tabular}{l|l|l} 
Conservative Media & $\begin{array}{l}\text { Reformist \& } \\
\text { Diaspora Media }\end{array}$ & Technology
\end{tabular}

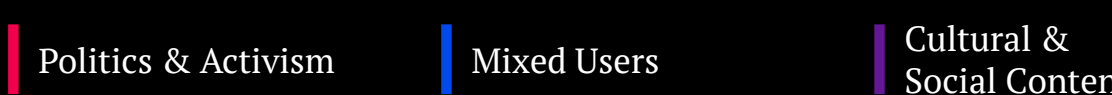


bas Aslani shares video of interview with former President Khatam

Seyyed Mohammad Khatami publishes a video on YouTube to tell people to go out and vote, and support the 'List of Hope"
سيد محمد خاتمى با انتشارى بيامى ويديويى در يوثيوب از مردم خواست بإى صندوقهاى رأى بروند و از بانى "ليست اميد" حمايث كنند

(6) View translation

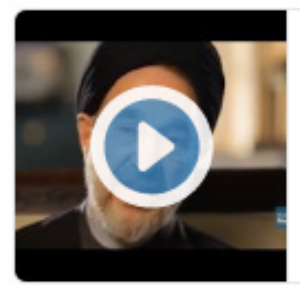

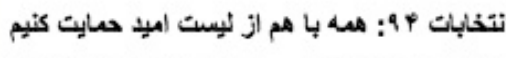

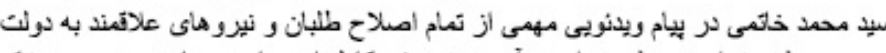

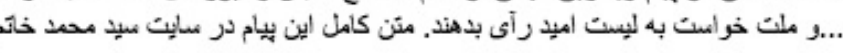

youtube.com

$\begin{array}{lll}\text { RETWEETS LKK } & \\ 14 & 40\end{array}$

-

5:21 PM - 21 Feb 2016

The campaign took off among clusters of reformist journalists, as well as among users in the Cultural Technology' and Mixed Users groups Perhaps predictably the network. Users elections, with both President Rouhani and former President Khatami's images superimposed. Figure 5.4 is an example of a post showing the candidate list for Tehran.
A user shares the 'List

of Hope' with their

followers

به بزرگ مرد اصلاحات \#خاتمى \#|عثماد مى كنم و راى ميدهم

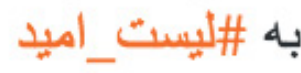

(-) View translation

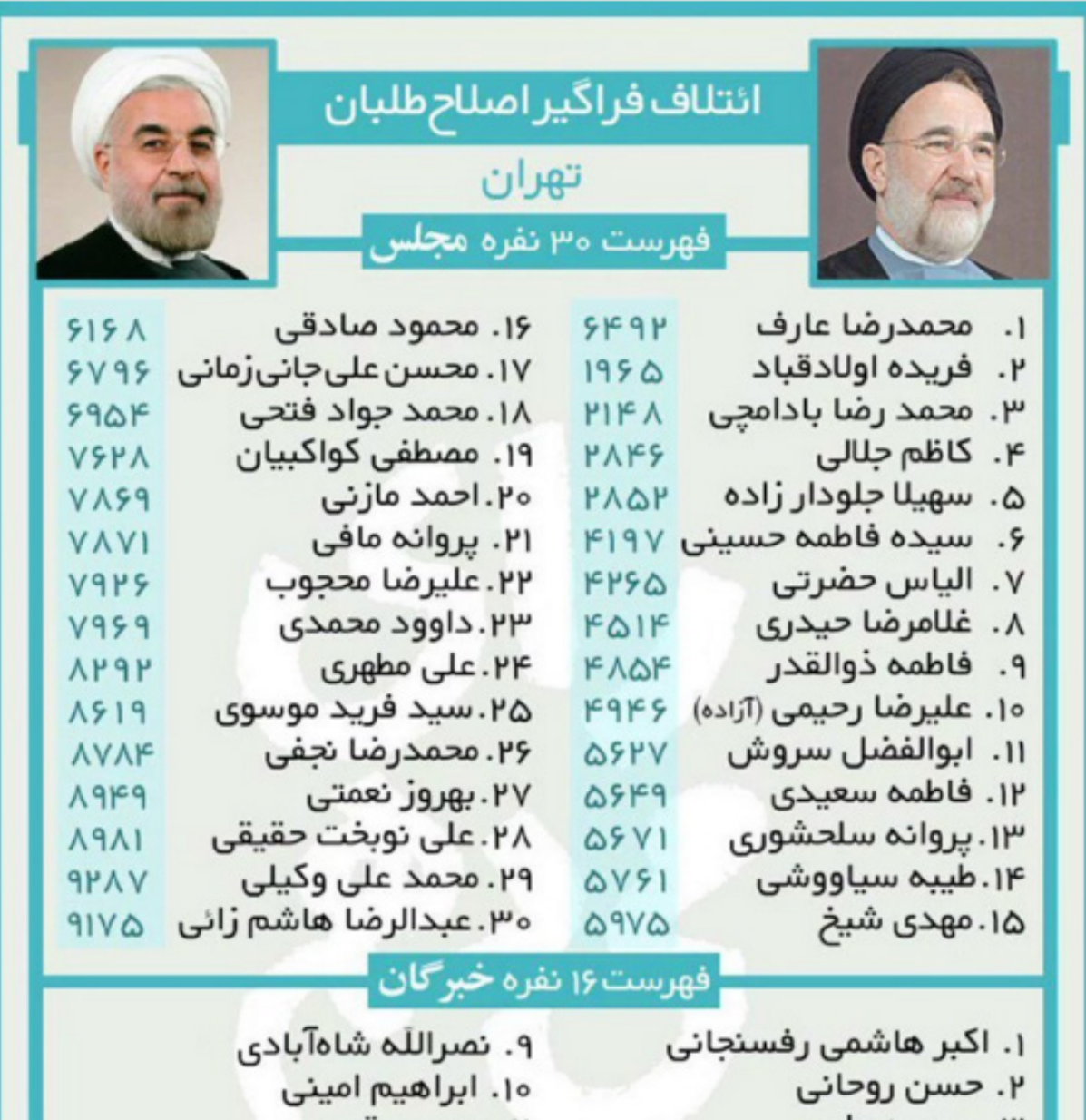

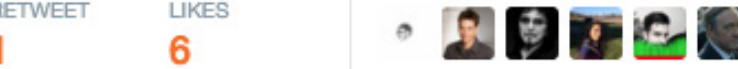

10:06 PM - 21 Feb 2016

เ7

By the end of the election campaign, users were emphasizing the importance of voting by citing examples of political dissidents and prisoners who had chosen to vote for the 'List of Hope.' Prior to the election there was a great deal of debate about the value of voting in the wake of the Guardian Council's mass disqualification of reformist candidates. 
Figure 5.5 is a post from a user describing how imprisoned human rights activist Narges Mohammadi cast her vote for the list from inside Evin Prison. Such tweets aimed to puncture cynicism around the elections, and demonstrate that even the most hardcore activists were willing to engage with the Islamic Republic's political system to ensure a rout of hardliners.

\section{[Figure 5.5]}

Narges Mohammadi's vote for the List of Hope makes the agenda

"Taghi Rahmani,

Narges Mohammadi's

husband, said: 'Narges

Mohammadi voted for

the \#ListOfHope from

inside the women's ward

of Evin prison."” wa

تقى رحمانى، همسر نرگس محمدى: "انركس محمدى به

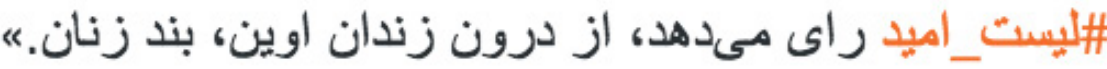

\section{9) View translation}

\section{Dromes}

خير كوتاه است دما خبر اين است كه نركس محمدى به لبست اميد راى ميدهد از

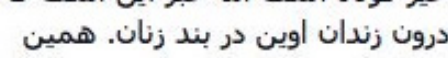

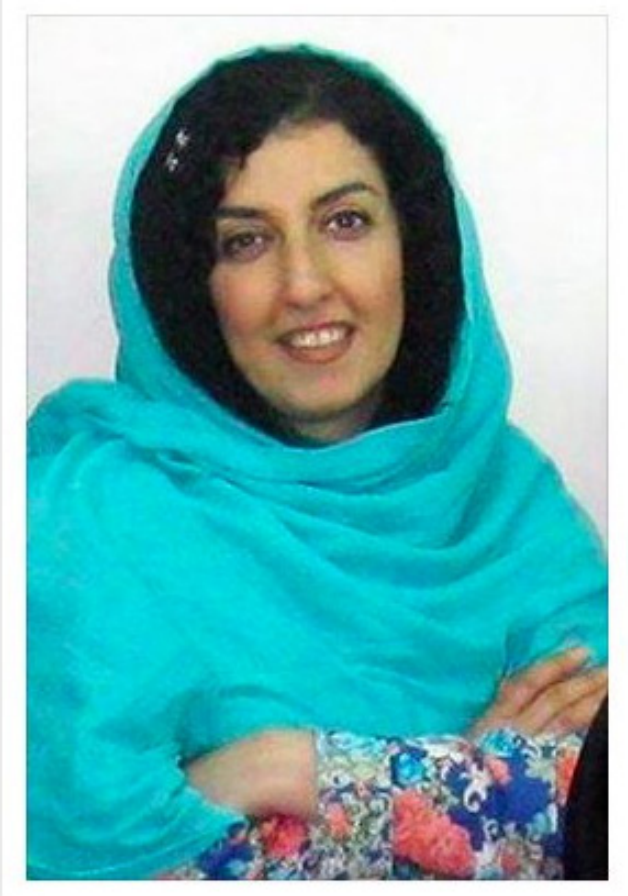

$\begin{array}{ll}\text { RETWEETS } & \text { UKES } \\ 26 & 105\end{array}$

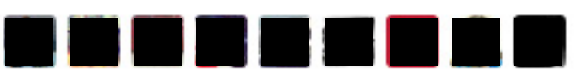

The user names of

individuals without

a high public profile

have been omitted for

security reasons. 
Users mentioning 'I'm Voting',

February 18-29, 2016

$-$

Terms:

راى ميدهمه

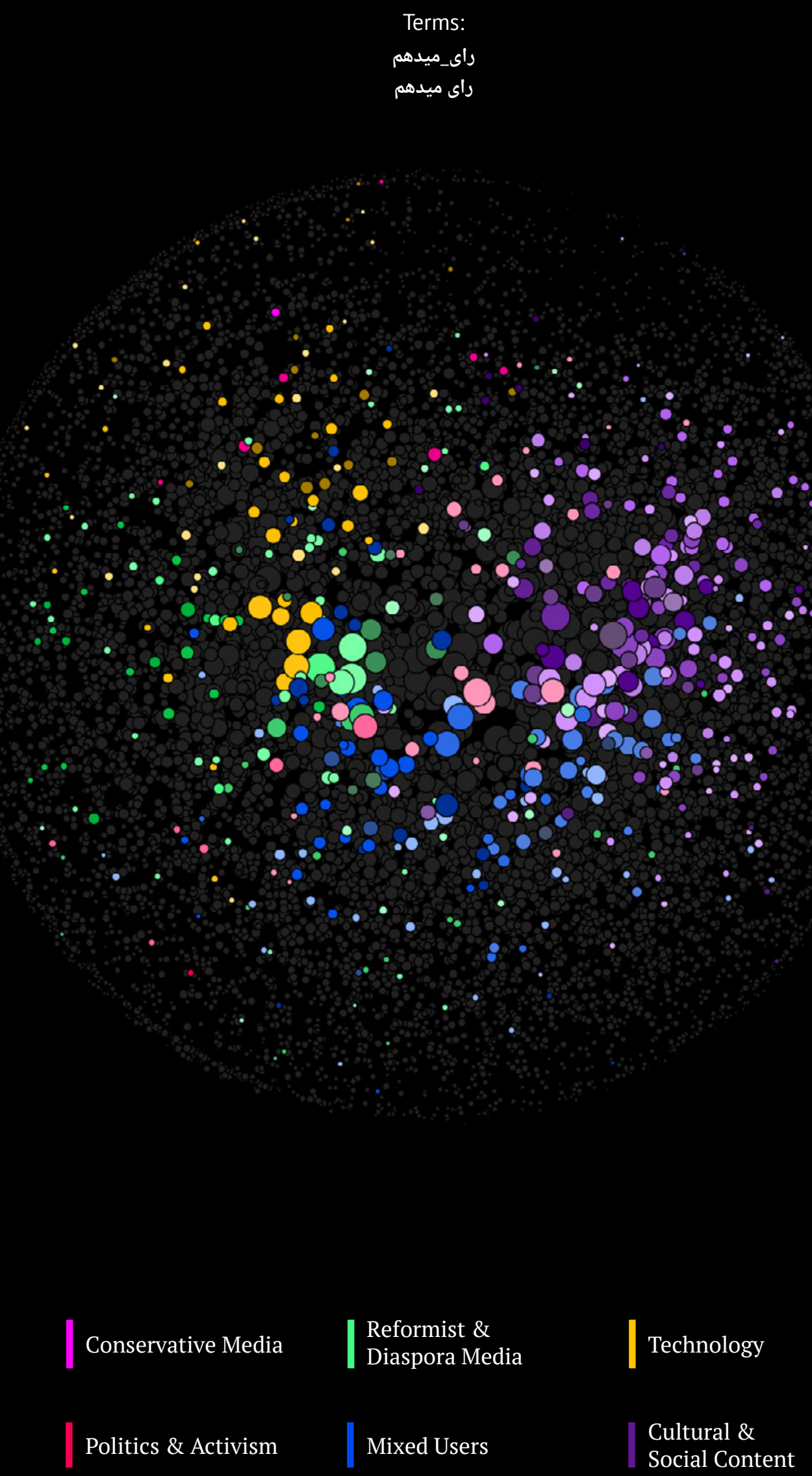

\section{Campaign 2: I'm Voting!}

In order to overturn the conservative and hardline dominance of the Majlis and Assembly of Experts, moderates and reformist activists saw raising turnout as a priority. In 2012, low turnout and a reformist boycott effectively conceded the legislature to some of the most hardline members of Iran's political establishment.

On the eve of the election, the popular Foreign Minister Mohammad Javad Zarif explicitly called for Iranians to come out to the ballot box in support of the Rouhan administration (see Figure 5.7).

[Figure 5.7]

Foreign Minister Zarif calls for voters to vote 'intelligently' to bring about positive change

\section{if 35 Javad Zarif @uZarif}

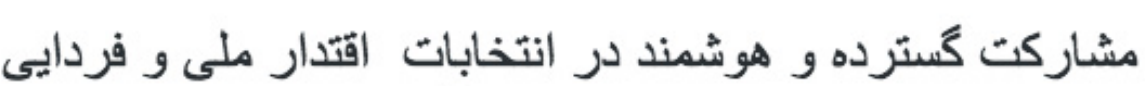

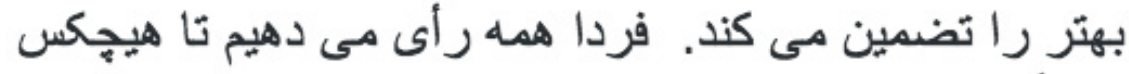
هيجگاه يك اير انى را تهديد نكند. (1) View translation

\begin{tabular}{ll}
\hline RETWEETS & LKES \\
$\mathbf{5 6 1}$ & $\mathbf{3 , 9 5 5}$
\end{tabular}

6:29 PM - 25 Feb 2016

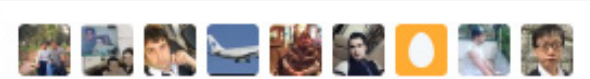

2+ Follow 
Activists had been mobilizing on Twitter for some time prior to Zarif's tweet to encourage moderate and reformist voters to turn out at polling stations. Figure 5.8 is a post from a reformist-leaning journalist quoting a speech from hardliner Ahmad Jannati about the imprisoned leaders of the Green Movement In it, he says:

The entrance to their house must be closed.

Their movement should be limited.

They shouldn't be able to send or receive any messages.

Their phone must be cut.

Their internet must be cut.

Their house should be a prison for them.

The post suggests that the only way to get rid of figures like Jannati is to come out and vote, and makes use of the 'I'm voting' (راى ميدهم) hashtag to this effect. The

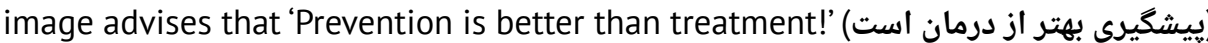

[Figure 5.8]

Journalist Ahmad Reza Ghani shares an image from the @WeVotelran Telegram channel,

quoting a speech from

Ahmad Jannati criticizing the leaders of the Green Movement and calling for their imprisonment.

"This photo is worth a thousand campaigns, it works! Let's disqualify this guy and his friends for once!"

\section{$2+$ Follow}

\section{AhmadReza Ghan} @Amarezzi

(2) Vew translation
[Figure 5.9]

A voter shares an image of their completed ballot and an ink-stained finger.

"I'm voting even though I'm sick."

اين عكس باه تنهايى قدر هزار كمبين، كار ميكنه! \#راى_ميدهم

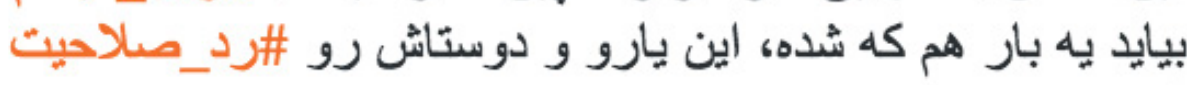
كنيم

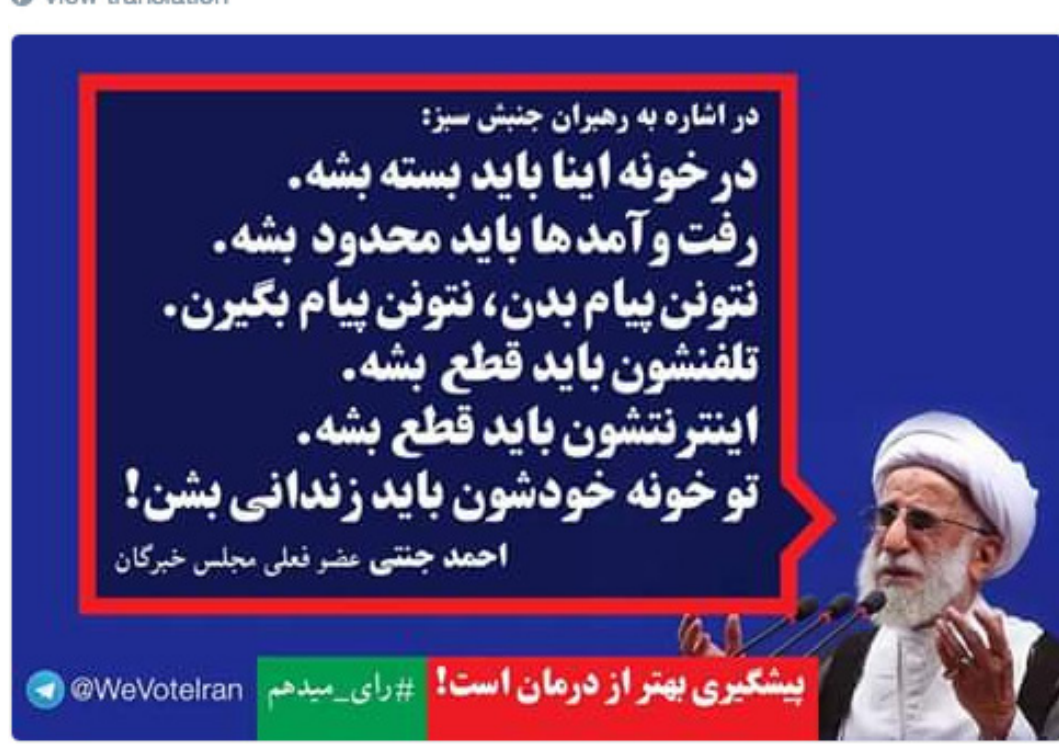

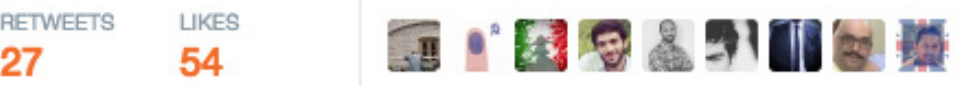

12:42 PM - 15 Feb 2016
On voting day the 'I'm voting!' campaign reached its peak, with many Iranians sharing pictures of their completed ballots or of ink-stained fingertips (see Figure 5.9) accompanied by the hashtag. In the end, voter turnout was reported to have exceeded 60\%51 - an improvement on 2012's seemingly dismal figures, which were never officially published by the Iranian government. ${ }^{52}$
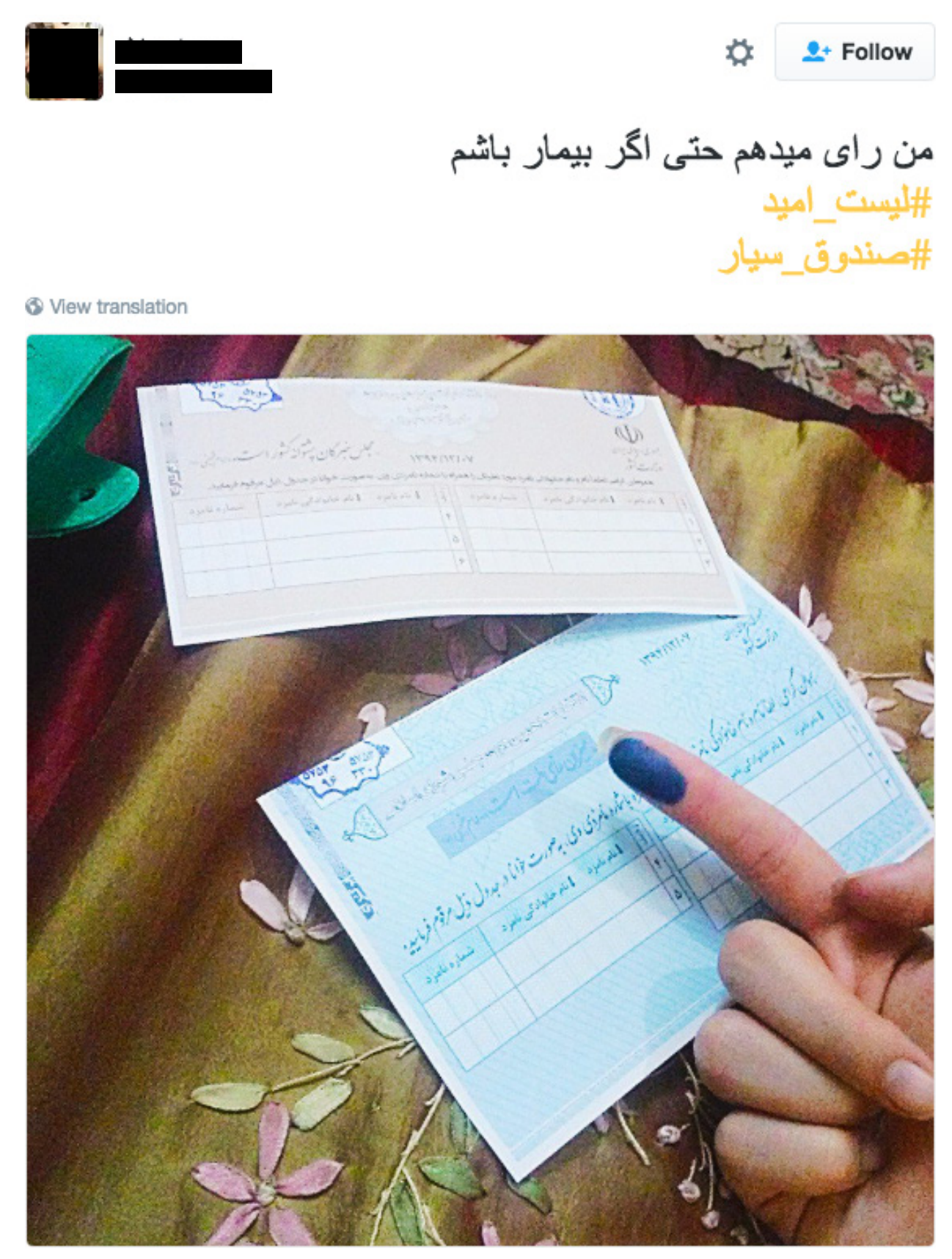

LKE

1:23 PM - 26 Feb 2016

51 Vishakha Sonawane, "Iran Elections 2016: Final Results To Be Announced In 3 Days, Reformists Performing Well," International Business Times 02/27/16, last accessed: 05/11/2016, http://bit.ly/ IBTIYEL

52 Saeed Kamali Dehghan, "Iran claims high turnout in elections - but there's no way to verify", The Guardian 03/04/2016, last accessed: 05/11/2016, http://bit ly/GualrEIT 


\section{Campaign 3: I Repeat}

In his message to the Iranian public, former President Khatami spoke particularly forcefully about the importance of voting for all the candidates on the 'List of Hope', stating:

"Those who care for reforms, improvement, progress in the country as well as removal of threats and limitations, need to try to vote for both the lists, all the individuals in both the lists, I repeat, vote for all the individuals in both the lists, to take steps on the path of the country's dignity and to boost stability and security in the country as well as to optimize and improve the affairs."

The phrase 'I repeat' was the subject of a number of memes on Iranian SNSs, with a number of high profile Iranians, including actress Baran Kosari, taking to the mobile app Dubsmash to lip sync to Khatami's speech.

Although Dubsmash posts were widespread on Facebook, on Twitter the "I repeat" meme took other forms. As visible in Figure 5.10, the term was repeated widely across the whole network, including the less overtly politically engaged 'Pop Culture and Literature' and 'Mixed Users' clusters.

Sadra Mohaqeq, the Society Editor for the reformist newspaper Shargh, posted a tweet imitating Khatami's language to mock the government's deployment of bulk SMS messages containing 'election hadiths' in an attempt to boost turnout (see Figure 5.11) 
[Figure 5.11]

Shargh journalist Sadra

Mohaghegh mocks an

election hadith:

"Resort to all the tools.

I repeat, resort to all the

tools, even the 'election

hadith' quoted from

Imam Sadeq."

به تمامى ابزارها متوسل شدن، تكرار مىكنم به تمامى ابزارها

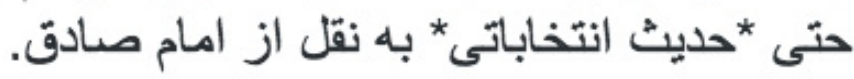

(6) View translation

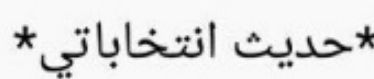

شخصي از امام صادق(ع) يرسيد:

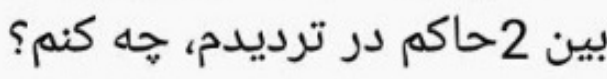

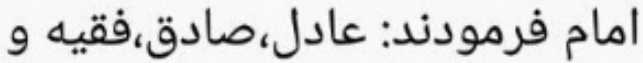

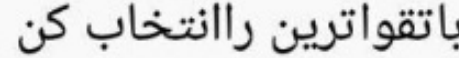

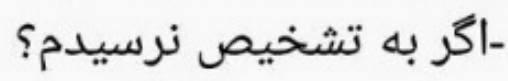

|2|R-MC|

Today 7:16 PM

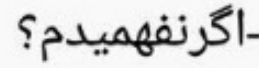

امام(ع):بنكرمخالفان آيين ماكدام

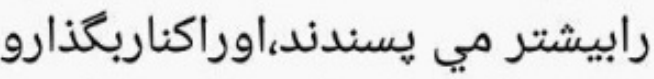

بيين كدام بيشتر آن هاراخشمكين

ميكند،اورا بركزين.

(كافي،جا،صاورا بركزين.

RETWEETS UKES

4:54 PM - 25 Feb 2016
0 
Users mentioning 'The English List', February 18-29, 2016

$-$

Terms:

ليست_انكليسى : ليسى

نفوذ

\section{Campaigns 4 \& 5: The English List // No To The UK!}

Although reformists and moderates made effective use of online campaigns such as the 'List of Hope' and 'I'm Voting', they weren't the only ones making use of SNSs to advance their electoral prospects. Conservatives waged a reactive campaign in opposition to the 'List of Hope' that attempted to characterize it as the 'English List'-an electoral slate cooked up by the British government and the BBC to undermine Iran's national independence and autonomy.

These accusations were first made by hardliners after a speech delivered by Khamenei in which he warned voters against being influenced by foreign powers and the $B B C,{ }^{53}$ but these accusations quickly made their way to social media

platforms, where they became a discussion topic for conservatives and incredulous platfors wh wh supporters of the List of Hope. Whereas the 'English List'was farly widely discussed across the network (see Figure 5.12), the 'No2UK' campaign was effectively isolated to the conservative sectors of the Twittersphere from which it originated (see Figure 5.13).

\begin{tabular}{|l|l|l} 
Conservative Media & $\begin{array}{l}\text { Reformist \& } \\
\text { Diaspora Media }\end{array}$ & Technology \\
\hline Politics \& Activism & Mixed Users & $\begin{array}{l}\text { Cultural \& } \\
\text { Social Content }\end{array}$
\end{tabular}


[Figure 5.13]

Users mentioning 'No to the UK!',

February 18-29, 2016

Terms:

No2UK

$\% \circ$

503

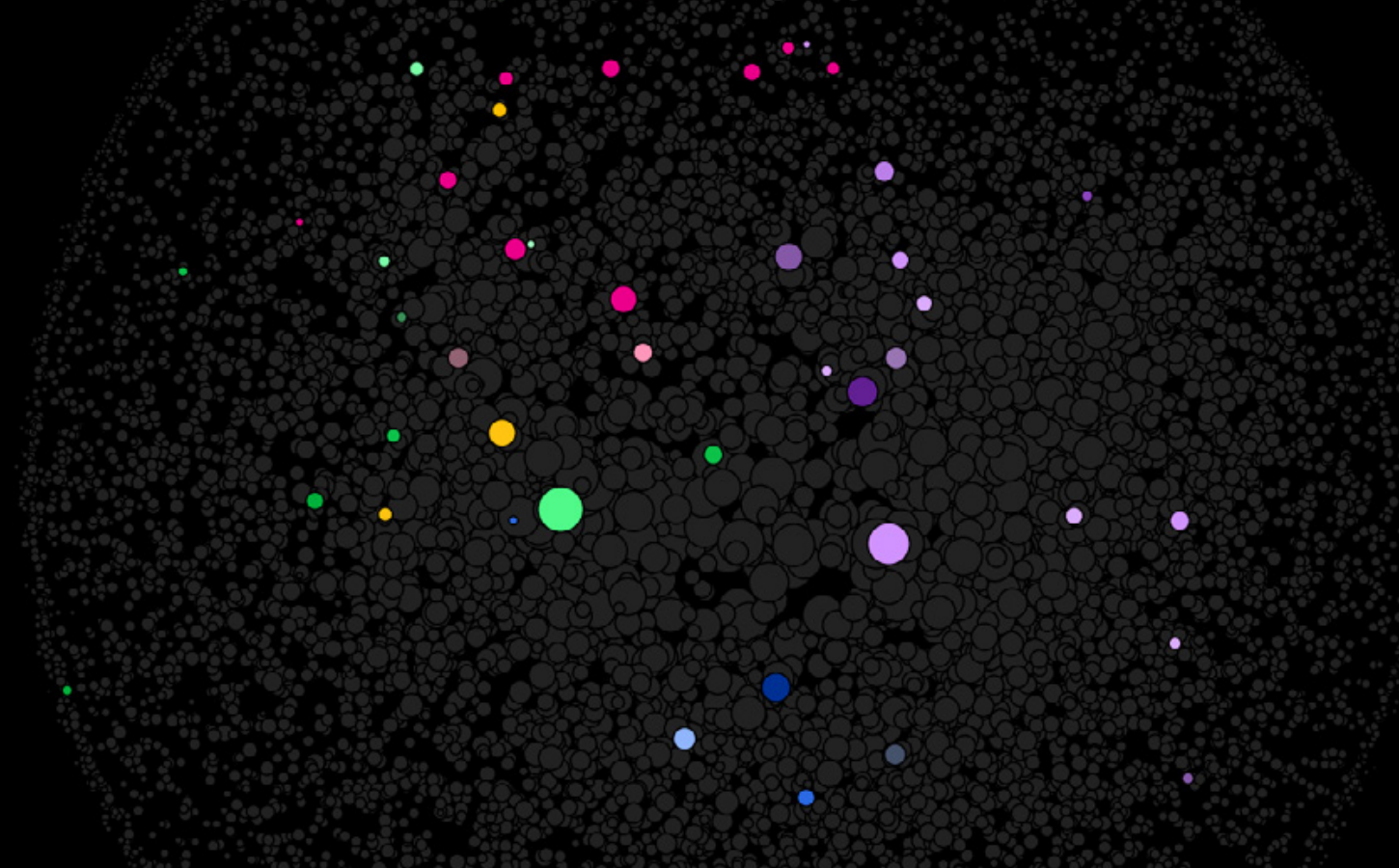

[Figure 5.14]

The Iranian SNS

Afsaran's Twitter account promotes the \#no2uk campaign on Telegram.

"A widespread presence of public figures and

artists in the 'No to

England' Campaign

Source: https://telegram

me/No2UK

\#No2UK \#No_to

England"

\section{1.) afsaran.ir}

2. Follow

حضور كسترده جهره ها و هنرمندان در كمبين \#نها_باه_انكليس منبع: telegram.me/No2UK تنه_با_انكليس \#NO2UK

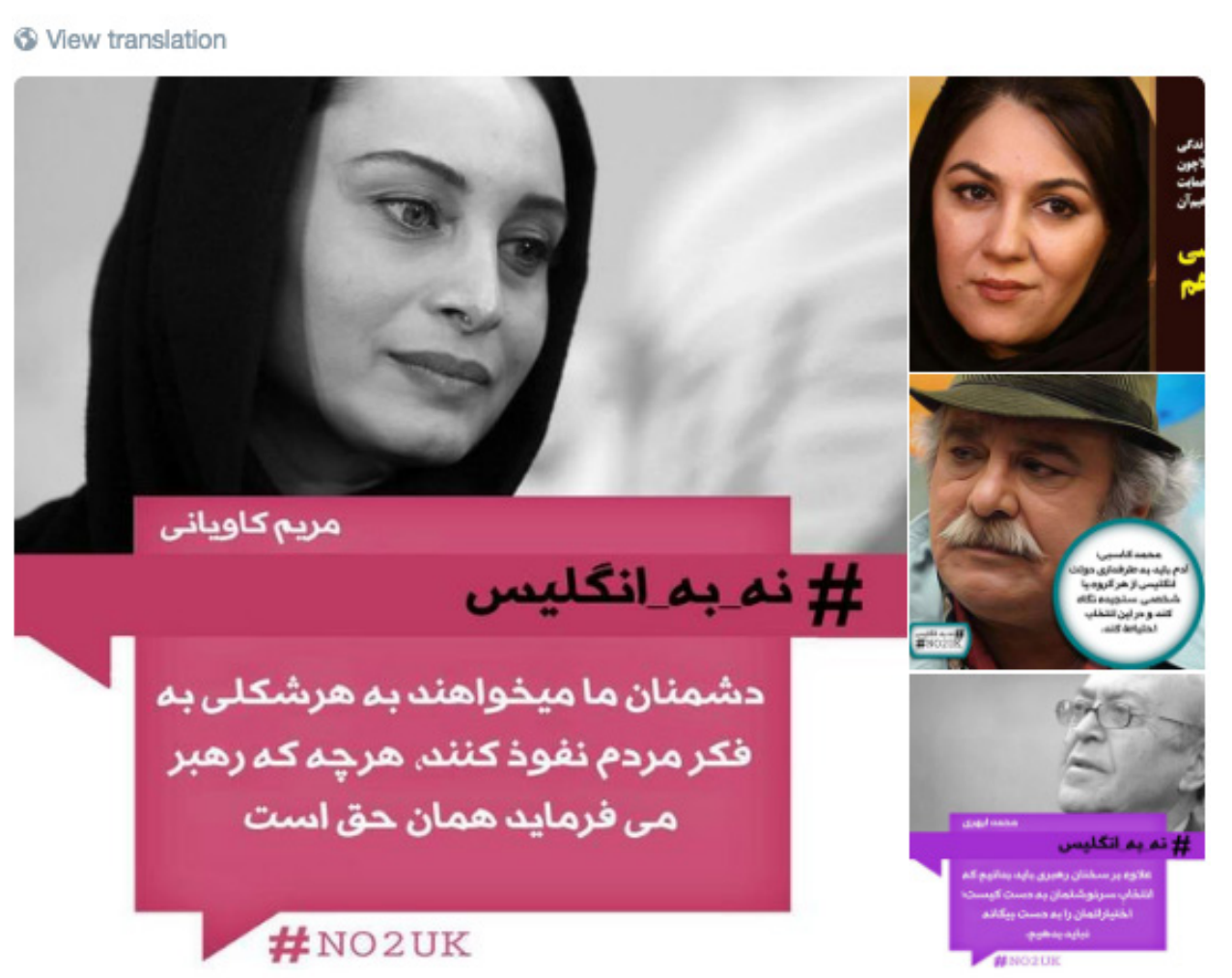

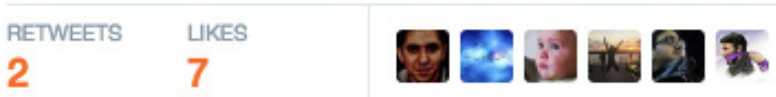

9:18 PM - 24 Feb 2016

\begin{tabular}{l|l|l} 
Conservative Media & $\begin{array}{l}\text { Reformist \& } \\
\text { Diaspora Media }\end{array}$ & Technology
\end{tabular}

\begin{tabular}{|l|l|l} 
Politics \& Activism & Mixed Users & $\begin{array}{l}\text { Cultural \& } \\
\text { Social Conten }\end{array}$
\end{tabular} 


\section{Conclusion}

This study has shown that the Iranian Twittersphere is a very different digital space than the Iranian blogosphere surveyed eight years ago. The segment of the Twittersphere examined in this study is largely political and effectively unipolar, being populated largely by reformist-leaning journalists, activists, and media consumers. Conservative users generally occupy spaces on the margins of the network, where they have formed generally quite insular communities, along with other 'fringe' political movements such as the Mujahedin-e Khalq and its collection of die-hard activists and spam bots.

The dominance of Iranian reformists and anti-establishment activists is reinforced by the size and strength of the Iranian diaspora in the Twittersphere and the level of its engagement with in-country journalists and activists. The high proportion of political activists and reformist-leaning journalists based outside Iran is even higher than we expected going into this project, and the extent of Iranian engagement with non-Iranian media sources is another interesting feature demonstrating the international character of Iran's political Twittersphere.

We also found that Twitter was a significant staging post for digital campaigners seeking to influence the outcome of Iran's legislative elections, although our impression was that it was something of a peripheral battleground: visuat medi impression was that it was something of a peripheral battleground. visual media shared on Twitter frequently contained links to Telegram groups and Facebook pages, suggesting that these alternative platforms (with greater popularity than Twitter inside Iran) were home to the more intensive campaigning efforts by political activists.

Aside from political purposes, we found that the Iranian Twittersphere is home to a large community of technology experts, bloggers, and entrepreneurs-some with a political focus (i.e. combating internet censorship and online filtering)-but many seemingly working within Iran's much-hyped tech sector. Although many users are tightly networked with diaspora-based tech accounts, the majority of users in the Technology group are based inside Iran, suggesting that many young tech enthusiasts see a bright future for the country's start-up scene. 
It would be inaccurate to describe the Iranian Twittersphere as an entirely

representative or accessible public space. The predominance of political content-

for the most part reformist in character-and the marginalisation of conservative voices is demonstrative of this (this is a feature that appears specific to Twitterconservatives have colonized Google+ in much the same way, whereas Facebook appears to harbor a more diverse and depoliticized user base, though further research would be required to confirm this). The lack of sizeable conservative communities arises less as a result of overt pressure from reformist-leaning users however, and is more likely a consequence of the government's decision to filter Twitter, while leaving Google+ and domestic social networks unblocked. We would hypothesise that conservative activists and journalists are less likely to make use of circumvention tools to evade state information controls, and so might be expected to congregate on online platforms not proscribed by the government.

The demographics of Iranian Twitter are also likely out of sync with Iranian society as a whole. While a large segment of the network only infrequently engages with political matters, users generally appear to be well-educated and are clearly techsavyy enough to use circumvention tools to get onto Twitter in the first place. pavy the challenges of accessing Twitter for many older and less tech-a fy lranians, the membership of the Twittersphere is therefore likely to be skewed towards younger, more educated citizens who are willing and able to circumvent the government's censorship system.

Our experiences in undertaking this study have illuminated some potentially rewarding future avenues of research that may provide valuable new insights into the usage of digital public spaces by Iranian citizens. The first and most pressing need is for alternative SNSs to be analyzed-first and foremost Iran's Facebook ecology, which appears to be the most well-developed in Iran by some distance. Another high priority candidate for mapping is the Persian-speaking Telegram network. Unfiltered in Iran, Telegram is a communication platform that has seen meteoric growth in the past year, attracting a massive influx of Iranian users from meteoric leaning media outlets and platforms. Mapping Telegram would perhaps offer the first opportunity to sketch out the features of a widely popular, and entirely uncensored Iranian digital public space. 


\section{Bibliography}

- BBC News, "Iran elections: Reformists make gains in Assembly of Experts", 02/29/2016, last accessed: 5/11/2016, http://bit.ly/BBCelexIr

- Bennett Jones, Owen, “An Iranian mystery: Just who are the MEK?" BBC News 04/15/2012, last accessed: 5/11/2016, http://bit.ly/BBCMEK

- Freedom House, "Freedom on the Net 2014" (2014), last accessed: 5/11/4/2016, http://bit.ly/ FrdHse14

"Freedom on the Net 2015", (2015), last accessed: 5/11/2016, http://bit.ly/FrdHse15

- Franceschi-Bicchierai, Lorenzo,"Twitter adds Iran, Cuba and 20 other countries to location options" Mashable 01/27/2015, (2015), last accessed: 5/11/2016, http://bit.ly/IrCubMsh

- Giacobino, Laurent, Arash Abadpour, Collin Anderson, Fred Petrossian, Caroline Nellemann, "Whither Blogestan: Evaluating Shifts in Persian Cyberspace", (2014), last accessed: 5/11/2016, http://bit.ly/shftsprsncbrspce

- Esfandiari, Golnaz, "The Twitter Devolution" Foreign Policy 06/08/2010, last accessed: 5/11/2016, http://bit.ly/TwDevlr

- Etling, Bruce, John Kelly, Robert Faris, and John Palfrey, "Mapping the Arabic Blogosphere: Politics and Dissent Online," New Media \& Society 12 (2010), pp. 1225-1243.

- Financial Tribune, "Must See Iran on Twitter", 10/16/2014, last accessed: 5/11/2016, http://bit. ly/MSeelr14

- Human Rights Watch, “No Exit: Human Rights Abuses Inside the MKO Camps", (2005), last accessed: 5/11/2016, http://bit.ly/HRW_MEK
- ILNA, "More than 14 million Iranians are on Viber, Facebook and Twitter", 02/06/2015, last accessed: 5/11/2016, http://brk.mn/ilna2015

- ISNA, "The results of the latest youth survey have been published", (2014), last accessed: 5/11/2016, http://bit.ly/lrVPNyth

- Katz, Leo and James H. Powell, “Measurement of the tendency toward reciprocation of choice," Sociometry 18, (1955), pp. 403-409

- Kelly, John, Bruce Etling, “Mapping Iran's Online Public: Politics and Culture in the Persian Blogosphere",(2008), last accessed: 5/11/2016, http://bit.ly/Brklr08

- Kelly, John, Vladimir Barash, Karina Alexanyan, Bruce Etling, Robert Faris, Urs Gasser, and John Palfrey, “Mapping Russian Twitter," Berkman Center Research Publication, 03/20/2012, last accessed: 5/11/2016, http://bit.ly/BrkRusTw

- Li, Yanhua,Zhi-Li Zhang, Jie Bao, “Mutual or Unrequited Love: Identifying Stable Clusters in Social Networks with Uni- and Bi-directional Links", (2012), last accessed: 5/11/2016, http://bit ly/NetMutT

- MacAskill, Ewan, "US confirms it asked Twitter to stay open to help Iran protesters", The Guardian 6/17/2009, last accessed: 5/11/2016, http://bit.ly/ GulrT09

- Morozov, Evgeny. The Net Delusion: How Not to Liberate the World. New York: Penguin Books, 2012.

- Musgrove, Mike, "Twitter is a Player in Iran's Drama", Washington Post 06/16/2009, last accessed: 5/11/2016, http://bit.ly/WaP09|r
National Council of Resistance of Iran, "Supporters of PMOI rally in Sweden for human rights in Iran", 09/29/2015, last accessed: 5/11/2016, http://bit. Ly/MEKHuR

- Norooz News, "What's behind the bogus testimony of Saeedeh Pouraghayi?" (Archived), 09/27/2009, last accessed: 5/11/2016, http://archive.is/vy0as

- Pfeifle, Mark, "A Nobel Peace Prize for Twitter?", The Christian Science Monitor 07/06/2009, last accessed: 5/11/2016, http://bit.ly/ChrScMlr

- Reporters Without Borders, "Internet Enemies Report 2012", (2012), last accessed: 5/11/2016, http://bit.ly/RwoB12

- Sabeti, Amin "Ayatollah Khamenei's website use social networks", Iran Media Program 12/18/2010 last accessed: 5/11/2016, http://bit.ly/KhamSoM

- Shahidsaless, Shahir, "Behind the recent turmoil in Iran's parliament", Al Monitor 01/18/2015, last accessed: 5/11/2016, http://bit.ly/AlMIrPar

- Small Media,"Ashton Talks, and the MEK Spams - Social Media Monitoring",03/24/2013, last accessed: 5/11/2016, http://bit.ly/AshlrMEK "Iranians' Best Five Reactions to Iran's Crappy Internet", (2015), last accessed: 5/11/2016, http://bit.ly/cppynetnov

"Iranian Internet Infrastructure and Policy Report, December 2015", (2016), p. 8 last accessed: 5/11/2016, http://bit.ly/lllPD15 "Iranian Internet Infrastructure \& Policy Report: July 2014", (2014), last

accessed: 5/11/2016, http://bit.ly/IIIP_Jul14 “Iranians Tweet On: The Deal”, (2015), last accessed: 5/11/2016, http://bit.ly/itoirnd "Iranians Tweet On: The Refugee Crisis",
(2015). Last accessed: 5/11/2016 http://bit.ly/itorfg

Unmasking the Arzeshi: Iran's Conservative Activists and the 2013 Presidential

Election",(2013), last accessed: 5/11/2016,

http://unmaskthearzeshi.com/

- Smith, Marc A. Lee Rainie, Itai Himelbolm, Ben Schneiderman, "Mapping Twitter Topic Networks: From Polarized Crowds to Community Clusters", Pew Research Center, (2014), last accessed: 5/11/2016, http://bit.ly/MapTwNet

- Tabnak Tehran, "How was the 'English List approved by the Guardian Council and the people?", 02/27/2016, last accessed: 05/11/2016, ttp://brk.mn/tabnaktehran

- Weaver, Matthew, "Iran's 'Twitter Revolution' was exaggerated, says editor", The Guardian 66/09/2010, last accessed: 5/11/2016, http://bit. ly/lrTwRGua 